\title{
A Simulation of the Tropospheric General Circulation with the MRI Atmospheric General Circulation Model Part I: The January Performance
}

\author{
By Tatsushi Tokioka, Akio Kitoh, Isamu Yagai and Koji Yamazaki \\ Meteorological Research Institute, Yatabe, Tsukuba, Ibaraki 305, Japan \\ (Manuscript received 11 January 1985, in revised form 24 August 1985)
}

\begin{abstract}
A performance study of the tropospheric general circulation with the MRI (Meteorological Research Institute) $\cdot G C M$ is presented for January. The MRI.GCM is basically identical to the UCLA.GCM (Arakawa and Mintz, 1974; Arakawa and Lamb, 1977) with minor changes to both the dynamical and physical processes of the model. The resolution of the model is $5^{\circ}$ and $4^{\circ}$ in longitudinal and latitudinal directions, respectively. The top of the model is located at $100 \mathrm{mb}$ and the atmosphere is divided into 5 layers. Both the sea surface temperature and the sea ice distributions are specified based on the climatological data, while other variables are determined within the model either prognostically or diagnostically.

The model has succeeded in reproducing basic characteristic features of the general circulation. Simulations are especially good in the tropics except that the mixing ratio of water vapor near the surface is underestimated in the model. Overall characteristics of the southern hemisphere are also simulated well. On the other hand some systematic disagreements between the model and the climatology are found in the vicinity of the Tibetan Plateau*. Northerly is too strong near the surface along the eastern coast of China, and easterly is also too strong in the southern periphery of the Plateau. This anticyclonic flow is cold and dry, and thus enhances evaporation in the Bay of Bengal and precipitation over the equatorial Indian Ocean. It is suggested that the effects of small scale mountain ranges should not be underscored because they determine low level flows and thus the heating distribution through the air mass transformation process over the warm ocean.

Another notable defect is the poor simulation of the Aleutian low both in its position and intensity. This is consistent with the too low static stability in high latitudes due to the excessively cold temperature in the upper part of the model in high latitudes. The maximum decrease in the static stability is found in the area from Alaska to the northwestern part of Canada, in agreement with the extensions of low pressure area in that direction.

Arakawa and Schubert's (1974) theory is adopted in parameterizing penetrative cumulus convection. Thermal and dynamical roles of the parameterization are studied through budget analyses of heat and zonal momentum in low latitudes.
\end{abstract}

\section{Introduction}

Almost twenty years have passed since a

* This term is used in this paper not in its ordinary meaning but in the meaning which includes the topography in the north-eastern part of China and in the southern part of east Siberia as well as the ordinary Tibetan Plateau. numerical simulation of the global atmospheric circulation was initiated by Smagorinsky (1963) and Mintz (1964). So many studies have been presented on the model performance since that time. Even when we restrict listings for realistic global simulation studies only, they are as many as follows; Manabe et al. (1970), 
Mintz et al. (1972), Kasahara and Washington (1971), Manabe et al. (1974), Manabe and Holloway (1975), Stone et al. (1977), Gates and Schleginger (1977), Corby et al. (1977), McAvaney et al. (1978), Manabe et al. (1979), Washington et al. (1979), Schleginger and Gates (1980), Pitcher et al. (1983), etc..

We performed a January simulation with the MRI (Meteorological Research Institute). GCM. A part of the results has been reported in Tokioka and Kitoh (1982). Compared with the results presented so far, our simulation itself does not show particular improvements. The model succeeded in reproducing basic climatic characteristics of the January tropospheric circulation. However, the model temperature in the lower stratosphere of high latitudes is excessively cold, the tropospheric westerly is too strong in the upper troposphere, and both the Siberian high and the Aleutian low are not simulated well, as most models so far reported the failure.

We do not go into details of every aspect of the model performance in this paper, as so many studies have already been published. Instead, we intend to place our emphasis on several aspects of the model which have emerged from our present study and seem not to have been recognized clearly so far. Among them are the simulation around the Tibetan Plateau, the simulation of the Aleutian low, the performance of penetrative cumulus parameterization, etc..

We describe an outline of the model in Section 2. Before describing on the mass and circulation system, heating distribution and thermal structure of the model are presented in Section 3. Section 4 is devoted for the description of mass and circulation system. In Secton 5, the performance of penetrative cumulus model is described both from the thermodynamical and the dynamical viewpoints. Several speculative discussions are extended in Section 6.

\section{An outline of the model and the simulation}

\subsection{Model}

The general circulation model of the Meteorological Research Institute (the MRI.GCM-I) is basically identical to the UCLA model described by Arakawa and Mintz (1974) and Arakawa and Lamb (1977), with minor changes to both the dynamical and physical processes of the model. Ground temperature, ground wetness, snow depth, atmospheric boundary layer depth and the gaps in physical variables at the top of the boundary layer are predicted by the model besides two components of horizontal wind velocity, temperature, the mixing ratio of water vapor and surface pressure. The surface albedo is determined by the model as a simple function of the surface boundary. The cloud amount, also, is determined diagnostically by the model and is used in the calculation of radiation. The geographical distributions of sea surface temperature and sea ice are prescribed, based on the climatological data, as a function of time. The model uses the actual diurnal and seasonal distribution of insolation. Thus the model atmosphere undergoes a diurnal cycle as well as an annual cycle. A very brief outline of the model is given in the following. For further details of the model, see Tokioka, Yamazaki, Yagai and Kitoh (1984).

\section{Horizontal and vertical structure}

Governing equations are approximated by a finite differencing method in both horizontal and vertical directions. In the vertical the model uses a modified $\sigma$-coordinate $\left(\sigma=\frac{p-p_{t}}{p_{s}-p_{t}}\right.$, $p$ is pressure), in which both the lower boundary (the pressure of which is $p_{s}$ ) and a prescribed pressure level near the tropopause $\left(p_{t}\right)$ are coordinate surfaces. In the horizontal direction the model uses a spherical coordinate. Locations of physical variables are shown in Fig. 1. The locations assure us best simulations of wave dispersions in a three dimensional space (Winninghoff, 1968; Tokioka, 1978). In the present simulation the top of the model is located at $100 \mathrm{mb}$ and the atmosphere is divided into 5 layers. The horizontal grid interval is $5^{\circ}$ and $4^{\circ}$ in longitudinal and latitudinal directions, respectively.

\section{Time differencing}

The time differencing used in the model 

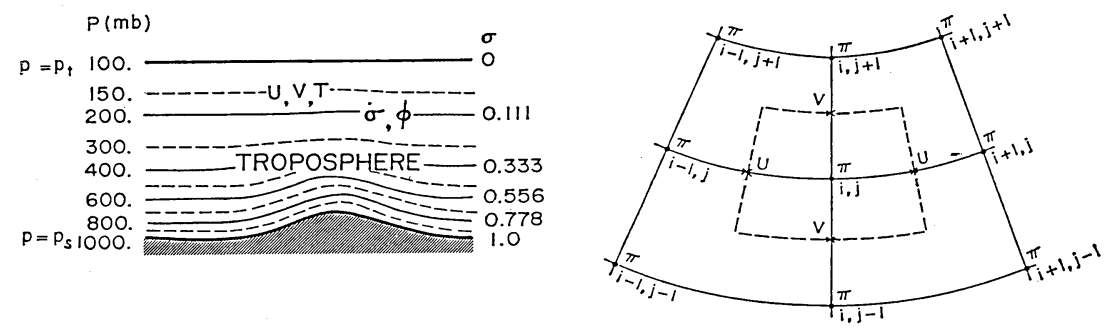

Fig. 1 The vertical (left) and the horizontal (right) structure of the model. $u, v, T, \dot{\sigma}$, $\phi$ and $\pi$ indicate eastward wind, northward wind, temperature, vertical velocity in $\sigma$ coordinate, geopotential and a thermodynamic variable, respectively.

for the basic dynamical terms is the leapfrog scheme with a periodical insertion of the Matsuno scheme. Time interval of integration is $7.5 \mathrm{~min}$ and the Matsuno scheme is inserted in every $60 \mathrm{~min}$. At the time step immediately before the Matsuno step, diabatic effects in the thermodynamic equation, diffusive effects in the momentum equation, sources and sinks in water vapor equation and the change of the planetary boundary layer (PBL) depth due to entrainment processes are computed and added to each prognostic variable.

\section{Radiation}

In order to compute radiative heating rate, the model uses Katayama's parameterization (1972). Details of the parameterization are found in Arakawa and Mintz (1974) or Tokioka et al. (1984). The mixing ratio of water vapor, tempetaure and cloud amounts used for the calculation of radiative heating rate are supplied by the model itself. On the other hand, the mixing ratio of $\mathrm{CO}_{2}$ is given as external data. The effect of aerosol particles is not considered in the model.

At present, two types of clouds are allowed to interact with radiation. The first is the cloud associated with the grid-scale supersaturation, i.e. the large-scale condensation, where we assume that the cloud fills the grid box entirely and that the cloudiness is 1.0. The second one is the cloud associated with sub-grid-scale penetrative cumulus convections. When the top of the cumulus is above $400 \mathrm{mb}$, the cloudtop layer is assumed to be filled with anvil clouds, and thus the cloudiness is set to 1.0 with the emissivity of 0.5 . In the present simulation cloudiness of shallow cumuli whose top are below $400 \mathrm{mb}$ is entirely neglected.

\section{Penetrative cumulus convection}

Arakawa and 'Schubert's theory (1974) is used to determine mass flux distributions due to penetrative cumulus convection diagnostically. Once the mass flux distributions are determined, diabatic heating rate due to cumulus convection is calculated with the use of thermodynamic budget equation of cumulus. The cumulus effect of momentum redistribution, sometimes called as "cumulus friction", is also calculated by assuming that momentum is transported passively with cumulus motions as a conservative quantity.

\section{Planetary boundary layer $(P B L)$}

PBL is modeled based on the parameterization proposed by Randall (1976) with some modifications (see Tokioka et al., 1984). In the parameterization, turbulent fluxes of heat, moisture and momentum are assumed to mix the PBL well with gaps at its top. The entrainment rate of the PBL is determined by considering budget of turbulent kinetic energy. Surface fluxes of sensible heat, moisture and momentum are modeled based on bulk method with the transfer coefficient proposed by Deardorff (1972).

\section{Ground thermodynamics and hydrology}

Ground temperature, snow mass and ground wetness are predicted by considering ground thermodynamics and hydrology after Katayama. For details of the parameterization, see Arakawa and Mintz (1974) or Tokioka et al. (1984). 


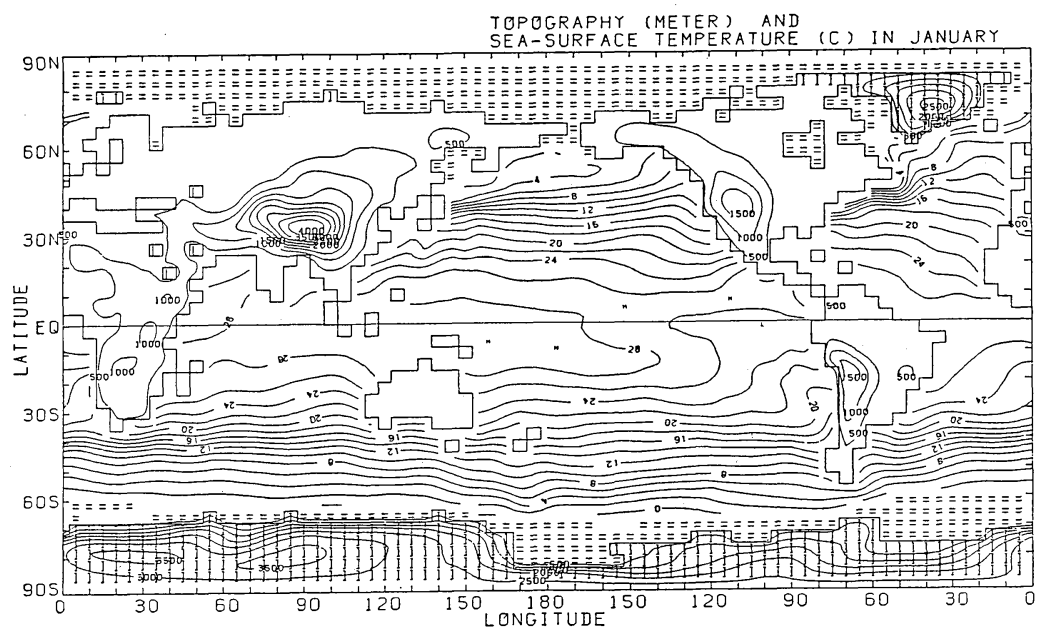

Fig. 2 Topography (unit: $\mathrm{m}$ ), sea surface temperature (unit: C), sea ice (indicated by the symbol "=") and ice sheets (indicated by the symbol " $\mathrm{l}$ ") distributions adopted for the present simulation.

\section{Sub-grid-scale diffusion}

Sub-grid-scale diffusion of momentum proposed by Smagorinsky (see Holloway and Manabe, 1971) is included in the momentum equation as well as the redistribution of momentum by penetrative cumulus convection. No other sub-grid-scale diffusions are included in any other fields.

\subsection{Simulation}

Originally the time integration.was started with a two-level model from a rest, dry and isothermal conditions with the topography and the land-sea distribution shown in Fig. 2. In this topography, two-grid-scale mountains are removed based on our finding that two-gridscale mountains systematically distort largescale flows through the erroneous mountain torque under the present horizontal differencing scheme. The sea surface temperature and sea ice distributions adopted for the present study are taken from USSR NAVY $(1974,1977)$.

The two-level model was integrated for two years. The initial condition for the fivelevel model was taken from this run. The five-level model was integrated for three months before the data used for the present study are taken. The present study is based on one January data within an annual cycle simulation. The model performances of July and annual cycle simulations will be reported in separate papers (Kitoh and Tokioka, 1985; Tokioka and Kitoh, 1985).

\section{Heating distribution and thermal structure}

\subsection{Radiative heating}

The difference of the net downward flux of radiation between the top and the bottom is the net radiative heating of the atmosphere, and is shown in Fig. 3. This shows that the atmosphere is being cooled through radiation rather uniformly at the rate of 50 to $150 \mathrm{~W} / \mathrm{m}^{2}$. The northern (winter) hemisphere is being more cooled than the southern hemisphere reflecting less absorption of the solar energy. The horizontal pattern has a good correlation with that of cloudiness (Fig. 4) in relatively low latitudes. Maximum cooling zones in the subtropics correspond to the less cloud zone, while minimum cooling areas in the western part of the North Pacific and the North Atlantic are determined through the combined effects of the relatively warm SST (sea surface temperature) and clouds. On the other hand minimum cooling over the Antarctica is due to low atmospheric temperature over the elevated surface.

The zonally averaged cloudiness is shown in Fig. 5. Observation is based on the value by Dopplick (1979). There is a systematic 


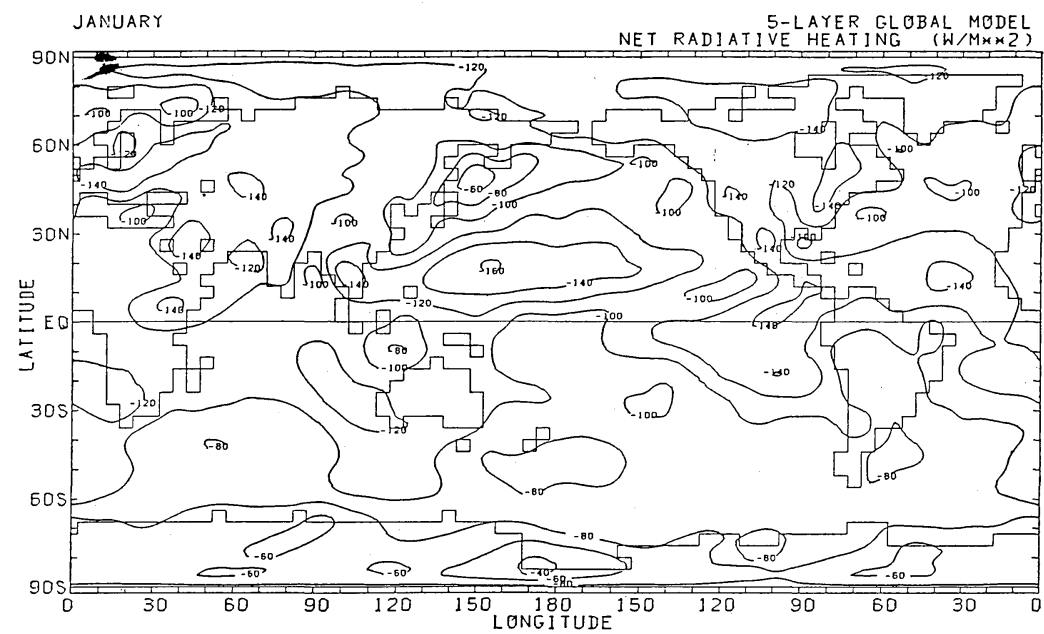

Fig. 3 Horizontal distribution of monthly averaged net radiative heating of the atmosphere produced by the model for January (unit: $\mathrm{W} / \mathrm{m}^{2}$ ).

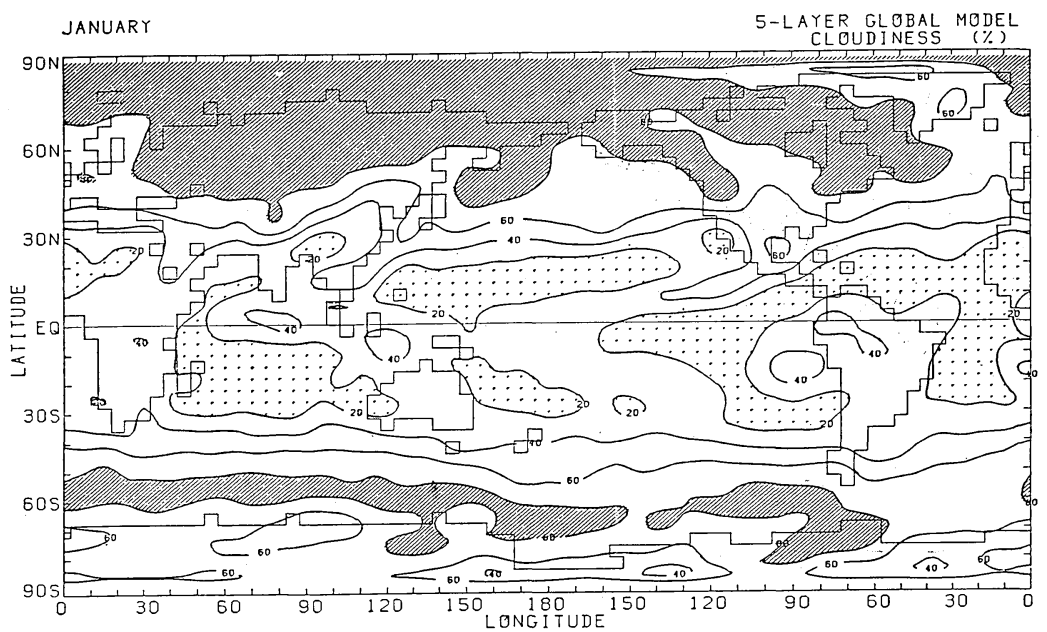

Fig. 4 Horizontal distribution of monthly averaged cloudiness produced by the model for January.

TOTAL CLOUDINESS

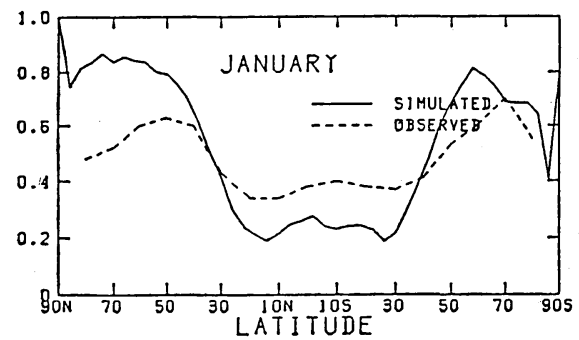

Fig. 5 Zonally and monthly averaged cloudiness for both the model and the climatology provided by Dopplick (1979). difference in the cloudiness between the model and the observation. It is underestimated in low latitudes and the opposite is true in high latitudes. The former may be due to the neglection of the cumulus cloudiness with its top below $400 \mathrm{mb}$. The excessive cloudiness in high latitudes is due to the excess of shallow large-scale clouds.

\subsection{Surface energy flux}

Energy is exchanged between the atmosphere and the earth's surface in the form of sensible and latent heat fluxes through tur- 


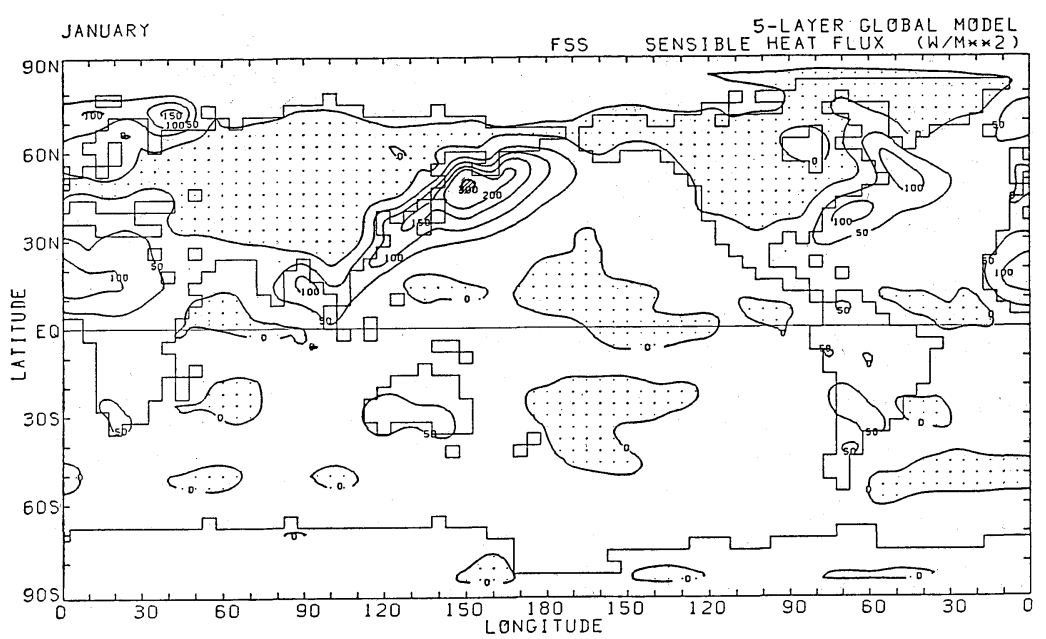

(a)

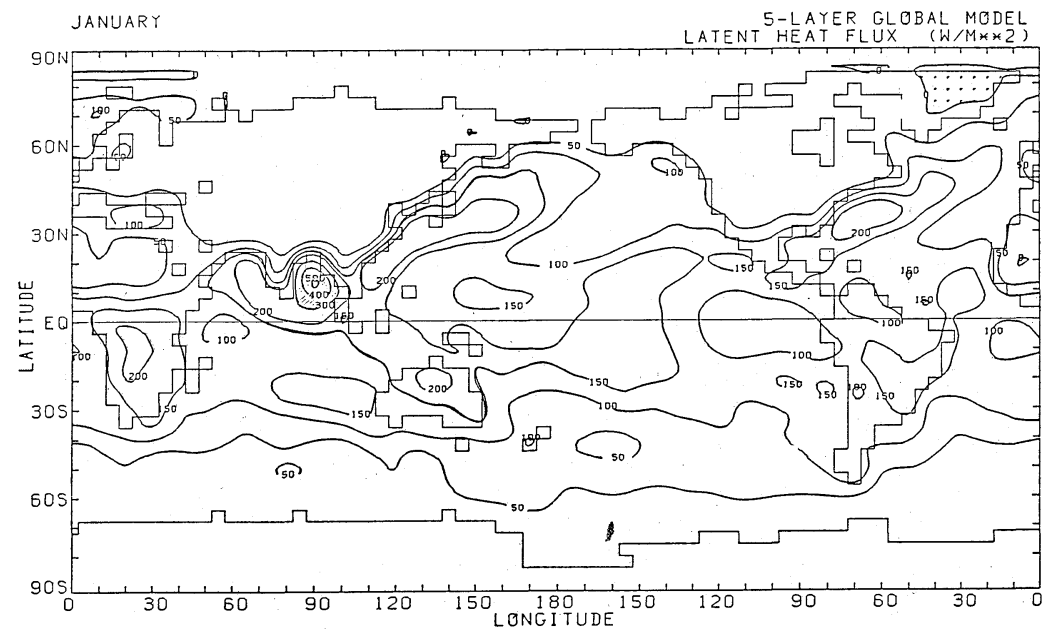

(b)

Fig. 6 (a) Horizontal distribution of monthly averaged sensible heat flux at the surface produced by the model for January (unit: $\mathrm{W} / \mathrm{m}^{2}$ ), and (b) Horizontal distribution of monthly averaged latent heat flux at the surface produced by the model for January (unit: $\mathrm{W} / \mathrm{m}^{2}$ ). Evaporation rate is obtained in $\mathrm{mm} / \mathrm{d}$ by dividing the numerical value in the figure by 28.9 .

bulent motions. Fig. 6(a) shows the horizontal distribution of monthly mean upward sensible heat flux at the surface. Pronounced upward energy flux exists off the east coasts of major continents in the northern hemisphere. Those areas coincide with the regions where cold air outflows over the warm ocean. There are also pronounced energy fluxes at the Barents Sea (northern portion of Scandinavian Pen.), where the sea surface is ice free. Flux is downward over the Eurasian and North American continents, while it is upward over the continents in low latitudes and the southern hemisphere.

Horizontal distribution of upward latent heat flux at the surface is shown in Fig. 6(b). The flux does not necessarily heat an air column above. The spacial variation of the flux is rather gradual. In broad sense, a dominant flux is seen in low latitudes. There 
are maxima off the east coasts of continents in the northern hemisphere, as is common to the sensible heat flux. However, maxima seen in the latent heat flux have shifted equatorward and slightly to the off-shore direction.

The largest flux is seen at the Bay of Bengal. The flux seems to be exaggerated in the model due to the dry and cool low level easterly wind, a part of which comes around the eastern periphery of China, i.e. "cold surge" (see Fig. 16(a)). In the southern hemisphere, there are maxima over southern Africa, maritime continent and over the southern part of Brazil.

Moist static energy flux is given by the sum of sensible and latent heat fluxes. The characteristics of the distributions are the combination of those seen in Fig. 6(a) and 6(b). It is interesting to note that moist static energy flux in the southern hemisphere is directed upward except some spotty areas in the Antarctica. In the northern hemisphere it is directed downward both in elevated areas

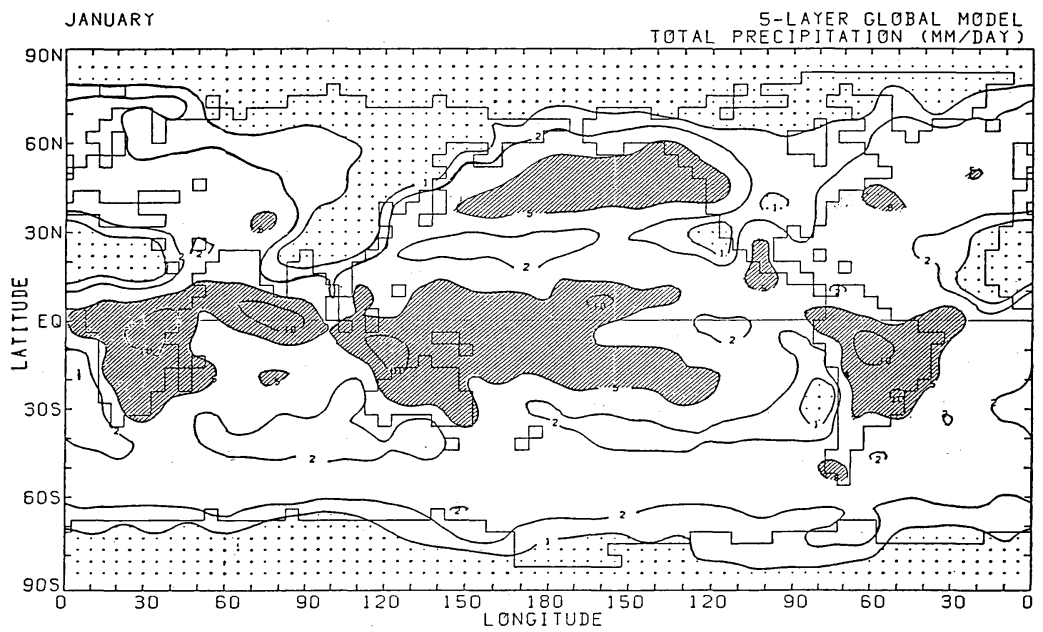

(a)

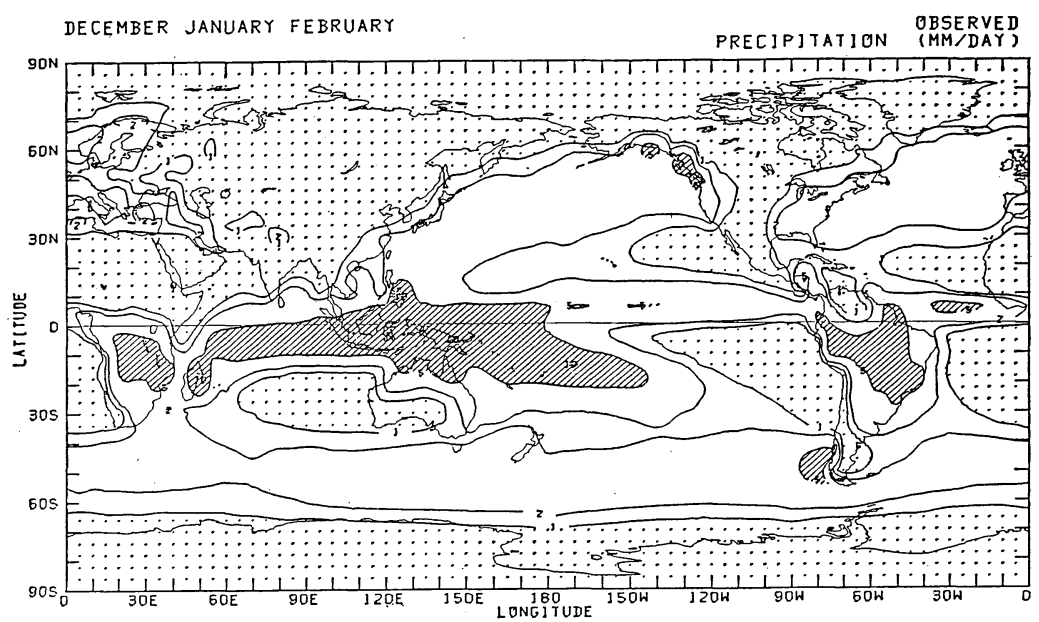

(b)

Fig. 7 (a) Horizontal distribution of monthly averaged total precipitation produced by the model for January (unit: $\mathrm{mm} / \mathrm{d}$ ), and (b) the corresponding climatological map obtained for December through February by Schutz and Gates (1972). The areas over $5 \mathrm{~mm} / \mathrm{d}$ and less than $1 \mathrm{~mm} / \mathrm{d}$ are shaded and dotted, respectively. 


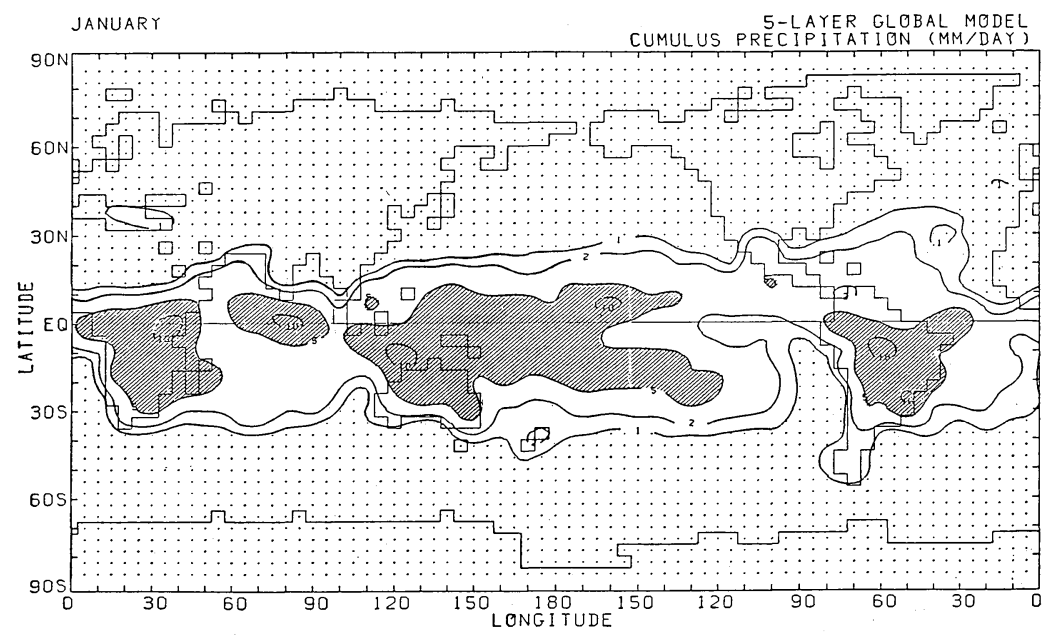

Fig. 8 Horizontal distribution of monthly averaged precipitation by penetrative cumulus convection produced by the model for January (unit: $\mathrm{mm} / \mathrm{d}$ ).

and in high latitude lands.

\subsection{Condensation heating}

The atmosphere is heated where and when condensation takes place. The condensation heating within an air column is proportional to the total precipitation. Fig. 7 shows the horizontal distribution of total precipitation together with the data compiled by Schutz and Gates (1972). Hatched and dotted areas in Fig. 7 show the areas over $5 \mathrm{~mm} / \mathrm{d}$ and less than $1 \mathrm{~mm} / \mathrm{d}$ respectively. Precipitation pattern is organized (Fig. 7(a)) and has a good correspondence with the climatological map (Fig. 7(b)). There are two major zones of precipitation. One is in the tropics and the other in the northern part of both the North Pacific and the North Atlantic. Minor peaks are found in the southern tip of the South America, in the southern part of Mexico and in the western periphery of the Tibetan Plateau.

High precipitation is found in the winter monsoon area*. The pattern in the equatorial Pacific reflects the characteristics of the ITCZ (Inter-Tropical Convergence Zone) and the

* A broad zone ranging from the equatorial Indian Ocean to the equatorial Central Pacific is an active monsoon area in January. This area is simply termed as "the winter monsoon area" in this paper.
SPCZ (South Pacific Convergence Zone) in spite of the coarse horizontal resolution. There are also high precipitations over lands in the tropics, i.e. over the southern Africa and Brazil. The precipitation in the tropics is mostly due to cumulus convections with their roots within the PBL (see Fig. 8). Precipitation in the model tropics is compared fairly well with Fig. 7(b), which is based on the average from December to February. However, a slight difference is noted over the equatorial Indian Ocean and the southern Africa. Precipitation over $10 \mathrm{~mm} / \mathrm{d}$ is found only in the model. Precipitation over the equatorial Indian Ocean seems to be exaggerated by the excessive moisture transport from the Bay of Bengal caused by the strong anticyclonic low level flow around the Tibeten Plateau. A further discussion on this point will be found in section 6. Precipitation is also high over the equatorial Central Pacific.

Subtropical latitudes are characterized with small precipitation. The North Africa, the southern part of the west coast of the United States, the northern portion of Chile are the areas of less precipitation and coincide with the climatological desert areas. There is also a zone of small precipitation along the eastern periphery of the Eurasian continent. This picture is consistent with a pronounced cold and dry anticyclonic flow around the Tibetan 
Plateau in the lower part of the atmosphere (see Fig. 16(a)). This anticyclonic flow is exaggerated in the present model. Further discussions on this will be found in section 6 .

Precipitation in mid-latitudes in the northern hemisphere is concentrated in the northern parts of the North Pacific and the North Atlantic. Those areas correspond to the paths of active cyclones. The most part of the precipitation is due to the saturation at the grid points (i.e. the large-scale condensation). A small part of it is caused by convections with their roots within the free atmosphere (i.e. the middle level convection). It is interesting to note that there are no concentrated areas of high precipitation in the middle latitudes of the southern hemisphere except at the southern tip of the South America. Precipitations occur rather uniformly in the longitudinal direction in the circum-Antarctic belt.

\subsection{Heating within the atmosphere}

Atmosphere is heated in three ways, i.e. through radiative heating, through sensible heat flux from the surface and through condensation heating. Fig. 9 shows a horizontal distribution of total heating integrated in the entire vertical air column. The hatched area in Fig. 9 indicates the heated area. We notice a dominant heating in the equatorial region and also over the western and northern parts of both the North Pacific and the North Atlantic. Extremely non-zonal structure is confirmed in the extratropics of the northern hemisphere. These features have been confirmed by Wei et al. (1981) for the winter of $1978 / 79$. The gross characteristic distributions found in Fig. 9 are commonly seen in the distribution of precipitation (Fig. 7(a)). This is especially so in the low latitudes. The major heating area ranges from the equatorial Indian Ocean to the equatorial Central Pacific. This zone corresponds to the active monsoon area in January, as revealed by Sumi and Murakami (1981). There are other peaks over the southern Africa and Brazil.

Cooling areas in the tropics are located over the eastern part of both the Pacific and the Atlantic, where the sea surface temperature is relatively low. There are elongated cooling zones in the zonal direction in the subtropics. The cooling zones both in the tropics and in the subtropics roughly coincide with the areas of less cloudiness (Fig. 4). The latitudes of the minimum cloudiness, however, are located in the equatorward side of the latitudes of the minimum heating over the western to the central Pacific.

Two pronounced areas are noted in the mid-latitudes of the northern hemisphere. Maximum heating located in the southern

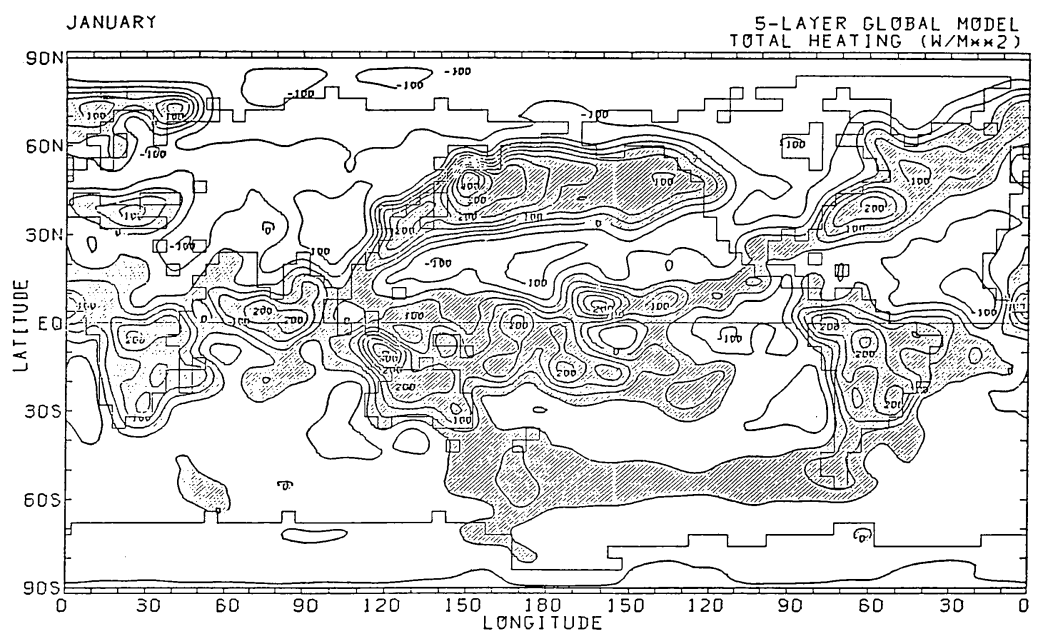

Fig. 9 Horizontal distribution of monthly averaged total heating for the entire air column produced by the model for January (unit: $\mathrm{W} / \mathrm{m}^{2}$ ). Hatched area indicates the heated area. 


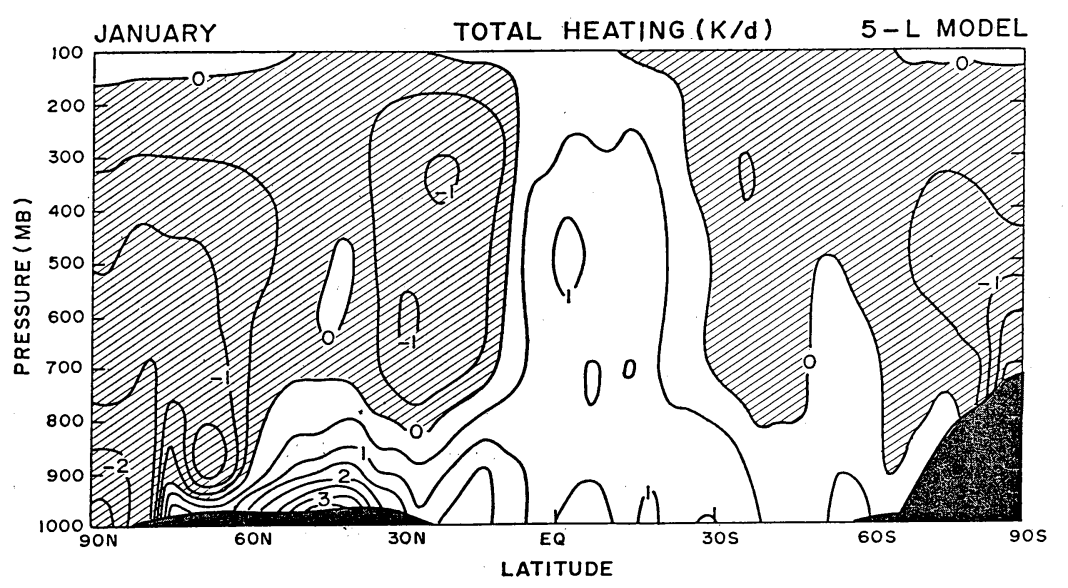

Fig. 10 Zonally and monthly averaged total heating rate of the model for January (unit: $\mathrm{K} / \mathrm{d}$ ).

part of the Sea of Okhotsk is more than 300 $\mathrm{W} / \mathrm{m}^{2}$, which is equivalent to the heating of $2.9 \mathrm{~K} / \mathrm{d}$. Sensible heat flux from the surface is mainly responsible for the pronounced heating off the east coast of the continents, while condensation heating is responsible in the eastern parts of the positive heating. A heated region is also found over the Barents Sea and the Mediterranean Sea. The major part of the energy in those areas is supplied in the form of sensible heat flux from the surface.

In the extratropics of the southern hemisphere, a zonally oriented weak heating zone exists around $50^{\circ} \mathrm{S}$. This latitude corresponds to the baroclinically active zone. Air column is being cooled over the Eurasia, the North America and the Antarctica.

Meridional distributions of zonally averaged heating are shown in Fig. 10. A deep heating in the tropics is caused by condensation of water vapor associated with deep cumulus convections. There are two maxima in the vertical direction; one is located around 500 $\mathrm{mb}$ level, and the other near the surface. Subtropical zone is being cooled except the layer below $800 \mathrm{mb}$. There is a pronounced heating near the surface in the mid-latitudes of the northern hemisphere, which is mainly due to the convergence of the sensible heat flux by turbulent motions within the PBL. The mid-troposhere in the mid-latitudes is slightly being heated due to condensation as- sociated with cyclone activities. There is a small and rather uniform heating by solar radiation (not shown). The area over $0.5 \mathrm{~K} / \mathrm{d}$ is found in the southern hemisphere as well as in the low latitudes. Cooling due to terrestrial radiation (not shown) is also uniform in the latitudinal direction. Maximum cooling over $3 \mathrm{~K} / \mathrm{d}$ is found near the surface in the subtropics and the polar regions.

Although we do not have good observed data to verify model results presented above, no serious contradictions to the widely accepted views of the atmospheric heating are found in them. We may point out that Fig. 10 may be compared fairly well with the results presented by Newell et al. (1974) except near the surface in low latitudes and in midlatitudes of the southern hemisphere.

\subsection{Temperature field}

Zonally averaged monthly mean temperature is shown in Fig. 11 together with the observed one. Temperature in the lower troposphere is compared fairly well with the observed data, while it is systematically low in the polar regions of the upper atmosphere. This situation is not essentially changed by simply raising the top of the model to $1 \mathrm{mb}$ (Tokioka and Yagai, 1984; Tokioka, Yagai and Kitoh, 1985; Mechoso, et al., 1982). Therefore we do not consider that the reason for the too cold temperature in the polar region of the lower stratosphere and a part of the 

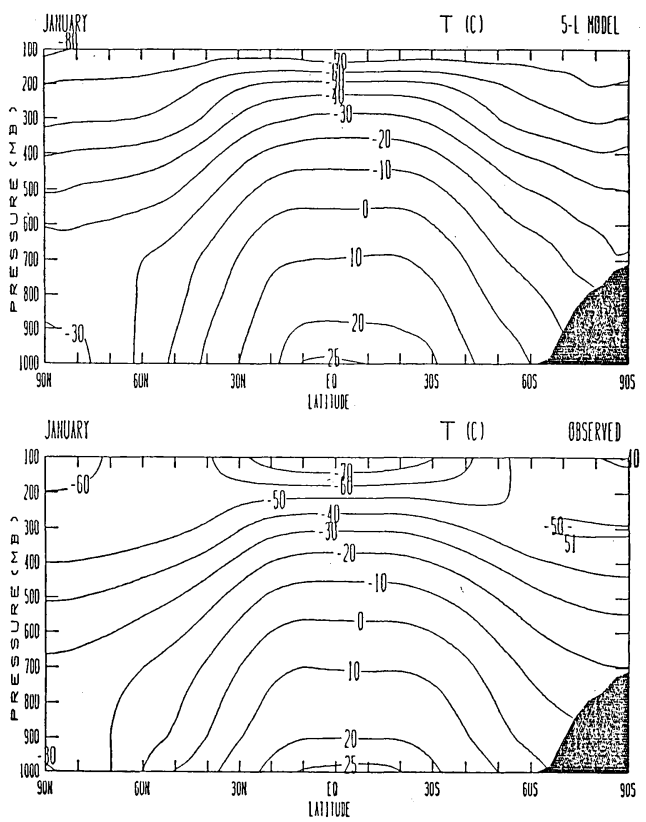

Fig. 11 Zonally and monthly averaged tempera. ture for January (unit: C). (a) model, (b) climatological map.

upper troposphere is simply explained by the spurious wave reflection of the planetary waves caused by the upper boundary condition of the model. Actually poleward sensible heat flux in those experiments is not small compared with the observational analysis. Ramanathan et al. (1983) has stressed the importance of accuracy in the calculation of radiative cooling, and demonstrated that the thermal structure in the polar region of the lower stratosphere is improved greatly in the NCAR CCM by careful calculation. Some revisions might be necessary for the present radiation model.

Fig. 12 shows a spacial distribution of a static stability together with the climatological map and the difference between them. The static stability is defined as $-\partial \theta / \partial p$, where $\theta$ is potential temperature and $p$ pressure, and is calculated for the air column below $200 \mathrm{mb}$. The area over $8 \times 10^{-2} \mathrm{~K} / \mathrm{mb}$ is shaded in Fig. 12(a) and (b), and positive area in (c).

The static stability is low and high in low and high latitudes respectively. High static stability is found over the continents in the northern hemisphere and over the Antarctica in consistent with low surface temperature in those areas. We see a similar feature in the climatological map. At the same time we notice a systematic differences between them, as shown in Fig. 12(c). The model atmosphere is more stable in low latitudes, while less so in high latitudes. The lower static stability in high latitudes is consistent with too low temperature in the upper part of the atmosphere as mentioned above. The higher stability in low latitudes is partially due to the upper lid located at $100 \mathrm{mb}$, as implied by Mechoso et al. (1982). The lid supresses mean upward motion and thus reduces adiabatic cooling rate which will be large otherwise. Tokioka, Yagai and Kitoh (1985) shows that the difference in the static stability reduces approximately to a half of that in (c) in low latitudes by raising the top of the model to $1 \mathrm{mb}$. The remaining difference might be explained by the excessive upward energy transport by cumulus convection, still insufficient intensity of the Hadley circulation or by less radiative cooling, or by the combination of them.

Apart from the zonally uniform systematic differences, we also notice several non-zonal differences in Fig. 12(c). There is a positive peak over the Indochina peninsula. This is caused by low temperature near the surface, which is due to the excessive cold air advection associated with the unrealistic anticyclonic flows along the eastern periphery of the Tibetan Plateau (Fig. 16(a)). The negative peak is found in the area from Alaska to the north-west portion of Canada. Excessive cyclonic activities are observed in the model atmosphere in that area. Further discussions on the model weakness noted above will be found in section 6 .

\subsection{Mixing ratio of water vapor}

The zonally averaged distribution of the mixing ratio of water vapor is shown in Fig. 13 together with the climatological map. Most of the water vapor is concentrated in the lower troposphere of low latitudes. The difference between the model and the climatology is found in the tropical region near the surface and mixing ratio of the model is less than 


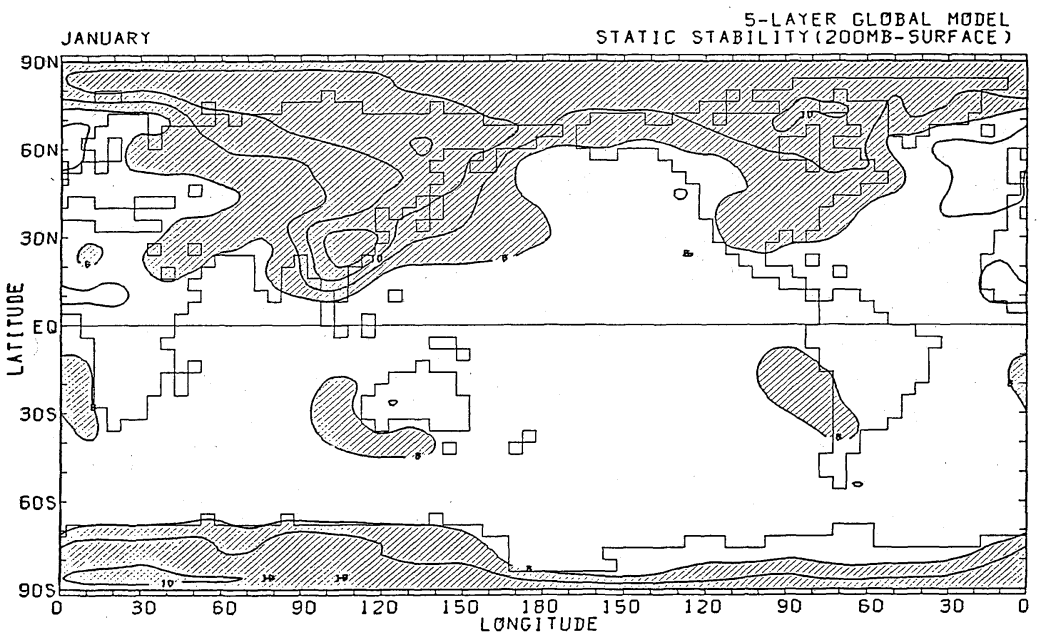

(a)

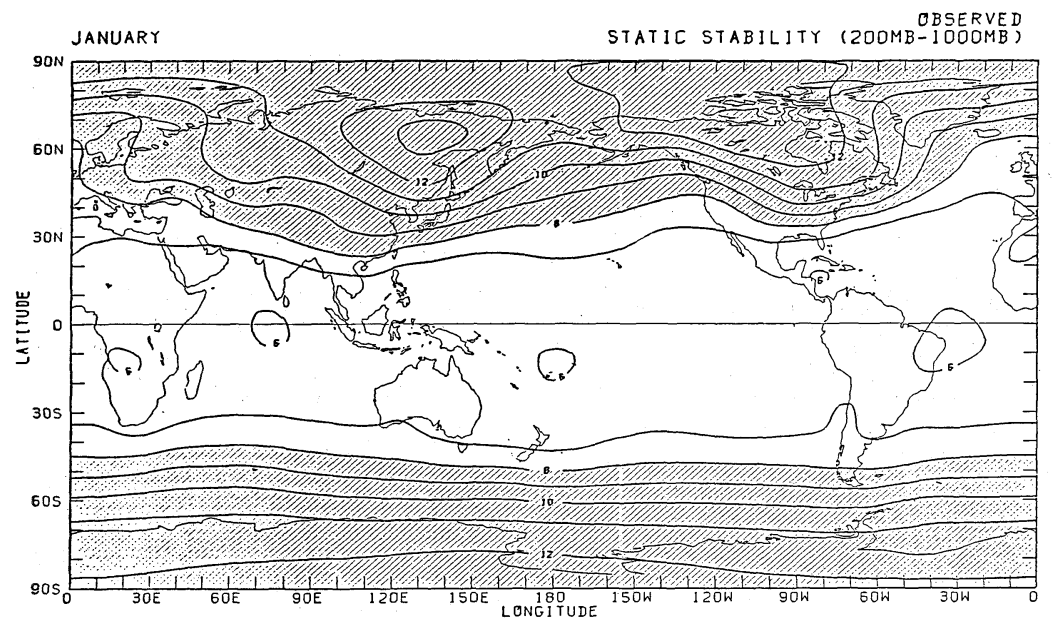

(b)

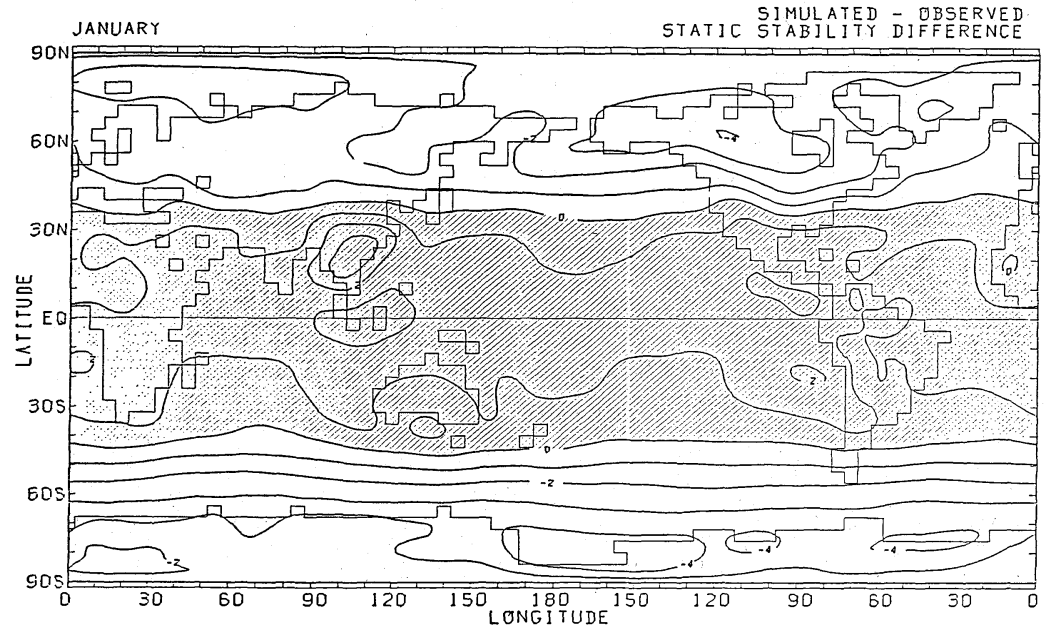

(c) 

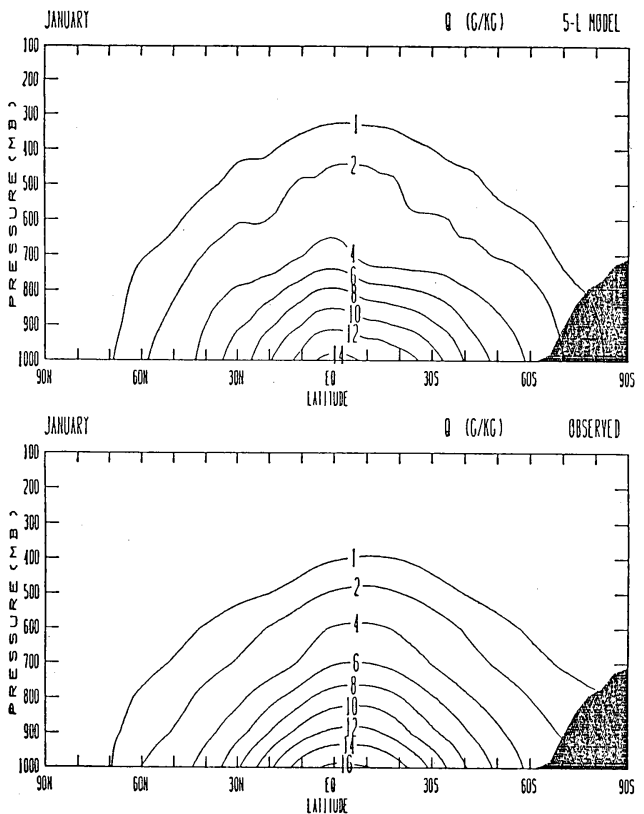

Fig. 13 Zonally and monthly averaged mixing ratio of water vapor for January (unit: $\mathrm{g} / \mathrm{kg}$ ).

(a) model, (b) climatological map.

that of the climatology by $2 \mathrm{~g} / \mathrm{kg}$. This difference seems to be connected with the present cumulus parameterization, and will be considered again in section 5 .

\section{Mass and circulation system}

\subsection{Sea level pressure}

Fig. 14 shows the monthly averaged zonal mean sea level pressure of the model together with the climatological value. The sea level pressure is low in the tropics, high in the subtropics, low in the middle latitudes and high in the polar regions. Although the model roughly simulates these climatological characteristics, it produces too low pressure in the mid- to high latitudes in the northern hemisphere. However, a good simulation of the very deep low in the circum-Antarctic zone is noted.

Horizontal distribution of the monthly averaged sea level pressure is shown in Fig. 15 together with the climatological map. In

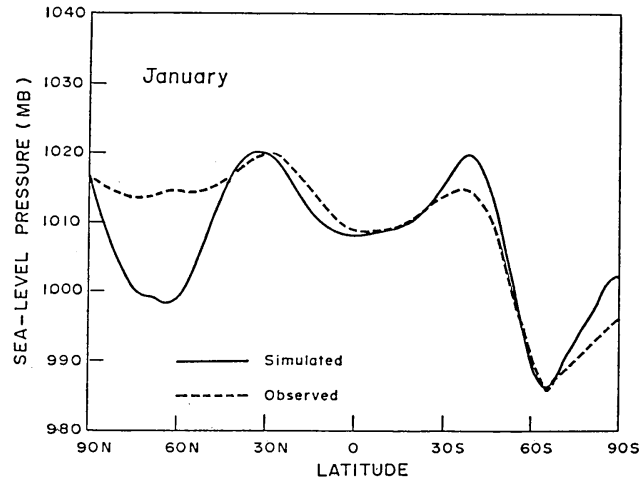

Fig. 14 Zonally and monthly averaged sea level pressure for January. Solid line and dashed line indicate that of the model and climatological value, respectively.

the model tropics, there are three centers of low, i.e. in the north-western part of Australia, over the South America and over southern Africa. Counterparts of them are found in the climatological map. Those areas correspond to the areas of high precipitation (see Fig. 7(a)) and large heating (Fig. 9).

Subtropical highs are intense over the eastern part of the ocean except over the South Pacific, where a major high is located in the central part. In the northern hemisphere, there are highs also over the continents. The so-called Siberian high is formed over the eastern part of the Eurasian continent. Compared with the climatological map, the center of the model high is shifted south-eastward and the elongation of the ridge in the north-eastward direction at the latitudes from $50^{\circ} \mathrm{N}$ to $70^{\circ} \mathrm{N}$ is not so intense in the model. This defect is also seen in other simulations such as Manabe et al. (1979), Pitcher et al. (1983), etc.. The south-eastward shift of the center produces a large baroclinic zone along the east coast of China with a pronounced energy flux from the warm sea surface (Fig. 6).

There is a deep low belt surrounding the Antarctica, as is known climatologically. This deep low belt in the model is consistent with

Fig. 12 Horizontal distribution of monthly averaged static stability $(-\partial \theta / \partial p, \theta$ potential temperature) calculated for the air column below $200 \mathrm{mb}$. (a) model, (b) climatological map based on Oort's (1983) data, (c) the difference between (a) and (b). Contour interval is $1 \times 10^{-2} \mathrm{~K} / \mathrm{mb}$. 


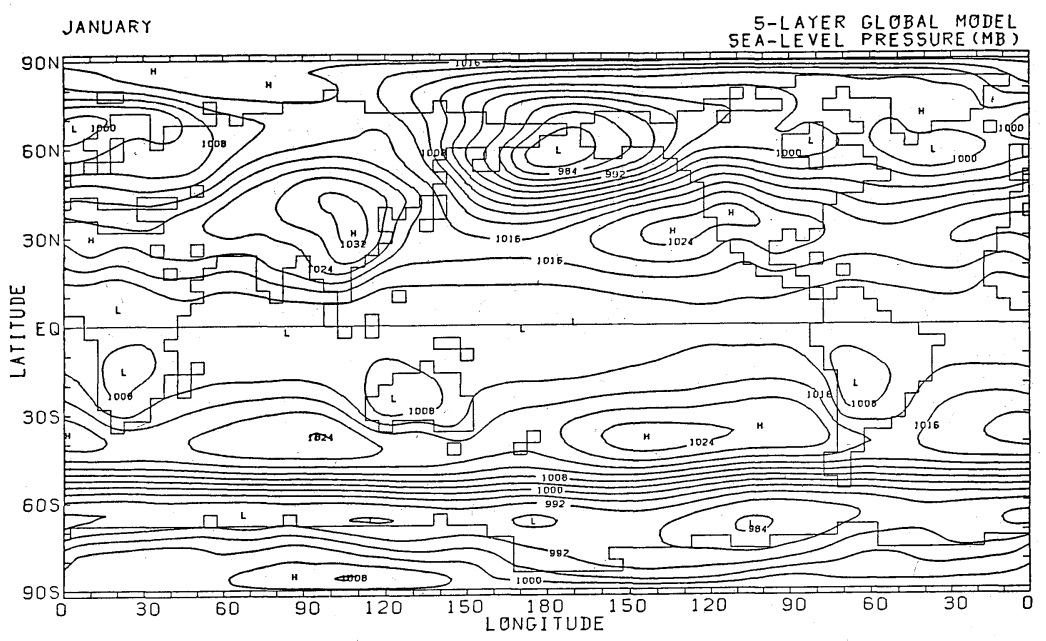

(a)

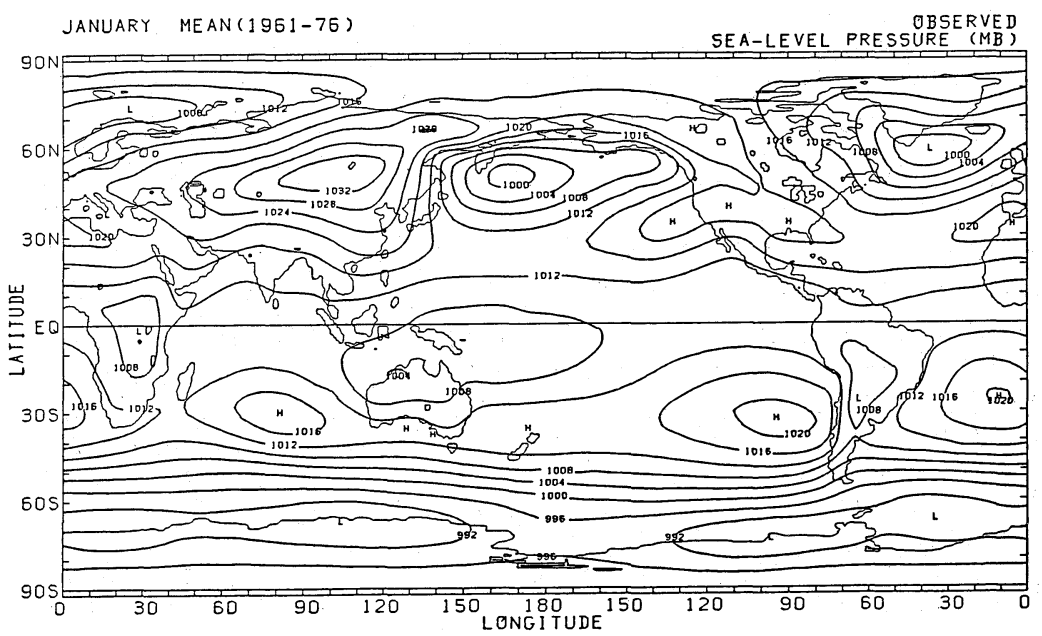

(b)

Fig. 15 Horizontal distribution of monthly averaged sea level pressure. climatological map based on the data by Godbole and Shukla (1981).

(a) model, (b)

intense surface westerlies around $50^{\circ} \mathrm{S}$ (Fig. 19(a)) where the earth's surface is entirely ocean except at Patagonia. The oceanic surface is smooth in the model (the roughness length is assigned the value $0.2 \mathrm{~mm}$ ), and intense surface zonal wind and thus intense pressure gradient in the meridional direction is easily maintained over there.

In the northern hemisphere there are two lows, one of them corresponds to the Aleutian low and the other to the Icelandic low. Sensible heat supply from the ocean in the extratropical latitudes tends to maintain low pressure on the eastside of the heating, because cold flow from high latitudes enhances heat supply from the oceanic surface on one hand and effectively counterbalances to the heating through the cold air advection on the other hand (Hoskins and Karoly, 1981; Webster, 1981). This picture roughly holds for those lows. It is noted that the former low is too deep and the position is shifted to the northeastward direction compared to its climatological position. Excessive deepening of the low might partially be related to the excessive heat supply off the eastern coast of 
Siberia, which might be closely related to the low level flow, and thus possibly to the unsatisfactory topography, i.e. to the lack of sub-grid-scale mountain effects, which might effectively reduces wind speed near the surface. The low pressure area extends over the north-west portion of Canada. The area just coincides with the area of decreased static stability (Fig. 12(c)). The weakness of the present model in simulating the Aleutian low will be considered further in the discussions.

Contrary to the Aleutian low, the Icelandic low is simulated well both in its position and intensity. However, the low is too deep over the area from the Norwegian Sea to West Siberia.

The pressure increases rapidly with increasing latitude in polar regions. Temperature above $300 \mathrm{mb}$ is systematically low in high latitudes in the present model (see Fig. 11 (a)). This might be responsible for the rapid increase of the sea level pressure near the pole.

\subsection{Wind vector at $900 \mathrm{mb}$}

Fig. 16 shows streamlines at $900 \mathrm{mb}$ of the model together with the climatological map based on Oort's (1983) data. The

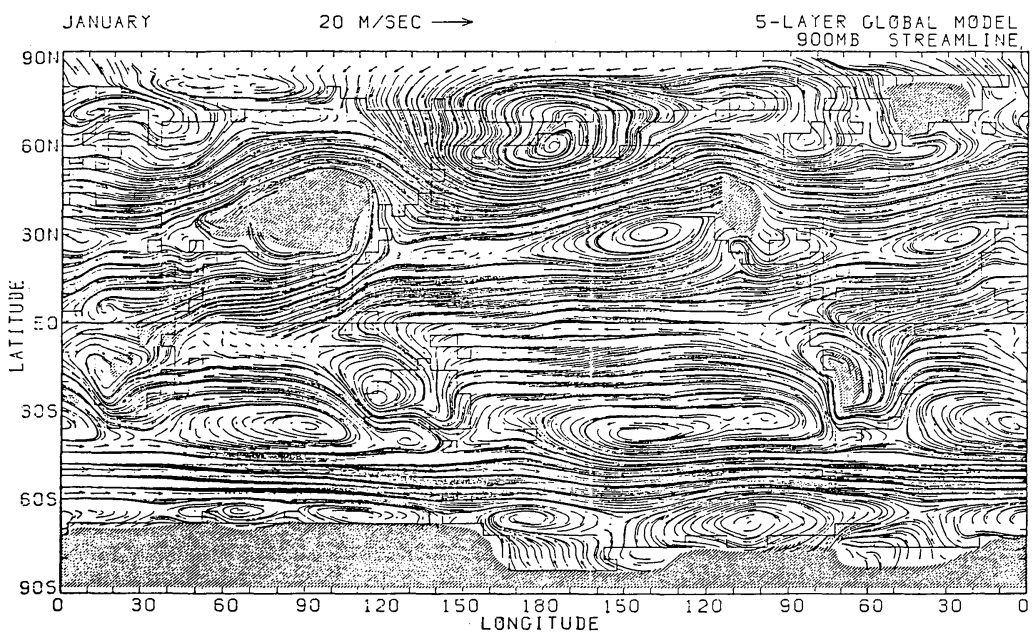

(a)

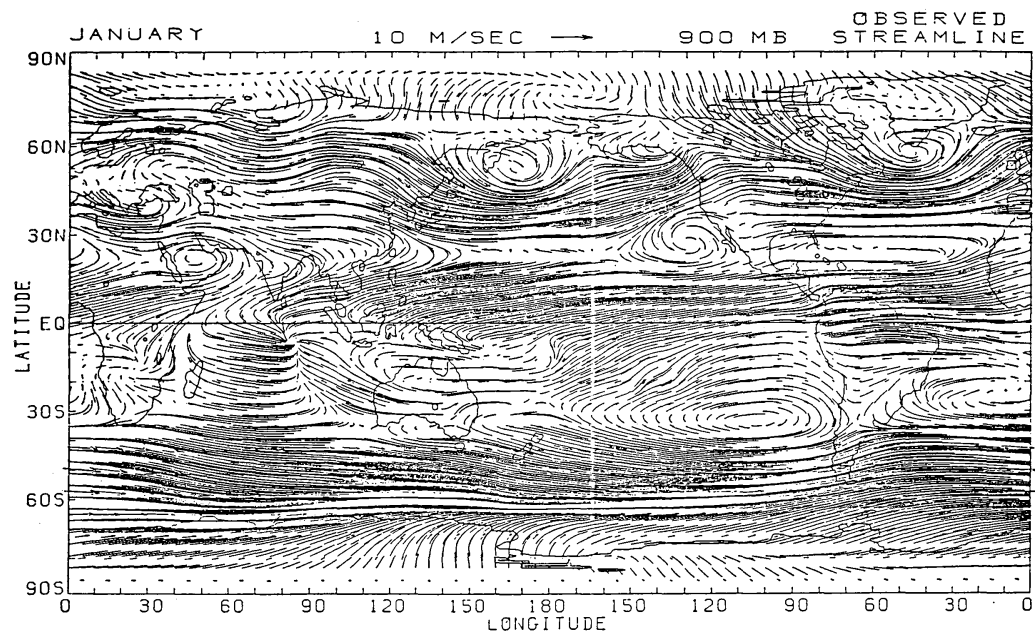

(b)

Fig. 16 Streamlines for the monthly averaged flows at $900 \mathrm{mb}$ for January. (a) model,

(b) climatological map based on data analyzed by Oort (1983). 
easterly prevails in low latitudes. Weak westerly is found around $10^{\circ} \mathrm{S}$ over Africa, between Indonesia and Australia and over the South America. These westerlies are associated with the low pressures over the southern Africa, Australia and the South America (see Fig. 15), and have a correspondence with the major peaks of heating in Fig. 9. In the climatological map (Fig. 16 (b)), there is a westerly over the Indian Ocean while no westerlies are found around $10^{\circ} \mathrm{S}$ over the South America. The present model fails to simulate these features. However, the present results fit better to the FGGE's January (Kanamitsu, 1981) in this respect. We consider that the disagreement mentioned above may just fall into the range of year to year variations observed in low latitudes. The cross equatorial wind is mostly northerly and the pronounced ones are found over the east Africa, between $70^{\circ} \mathrm{E}$ and $130^{\circ} \mathrm{E}$ (the winter monsoon area) and over the South America. These longitudes roughly coincide again with the FGGE's case.

In the subtropical latitudes of the southern hemisphere, anticyclonic flows prevail over the ocean. No counterpart is found over the Indian Ocean in Fig. 16 (b). There might be some problems in the observed data in this region. The major center of the anticyclonic flow in the South Pacific is found around $145^{\circ} \mathrm{W}$ in the model, while it is located around $105^{\circ} \mathrm{W}$ in the climatology. Minor peak is found in the model near the latter longitude. In Fig. 7 (a) we find a peak of precipitation along the SPCZ. Enhanced heating zone exists along the SPCZ (see Fig. 9). This heating forms a weak trough there (Fig. 15 (a)), splits a subtropical high into two and acts to maintain the high over the central South Pacific.

There are several cyclonic vortices along the Antarctica. An organized downslope wind from the Antarctic plateau is seen to enter the vortex over the Ross Sea.

Anticyclonic flows extend zonally along the $30^{\circ}$ latitude of the northern hemisphere. The centers of the anticyclonic flow are located in the eastern side of both the Pacific and the Atlantic in accord with the cli- matology. There are minor centers of anticyclonic flow over the western part of the Pacific and the Caribbean Sea. The anticyclonic center the Arabian penninsula (Fig. 16 (b)) is shifted northward in the model. Around the Tibetan Plateau is found a strong anticyclonic flow. Compared with the climatology, a major difference is found along the eastern periphery of the Plateau. There is a strong northerly in the model, while weak westerly in the climatology. The strong northerly on the eastern side of the Plateau goes around to maintain strong easterly along the southern periphery of the Plateau.

There is a strong cyclonic flow with its center near the Bering Straight. The center has shifted northward as well as eastward from the climatological position.

\subsection{Wind vector at $200 \mathrm{mb}$}

Fig. 17 shows streamlines at $200 \mathrm{mb}$ of the model together with the climatological map based on Oort's (1983) data. In the equatorial zone, three pairs of anticyclonic circulations roughly symmetric with respect to the equator are dominant. These types of motion have common features to those theoretically obtained when heat sources or vorticity sinks are placed at the equator (Matsuno, 1966; Gill, 1980; Lau and Lim 1984 ; Kasahara, 1984 and others). In Fig. 9, we can find a heating at each corresponding area. As the center of the heating is shifted in the southern hemisphere, anticyclonic flow in that hemisphere is dominant. Exception is the one located to the south of Japan, the intensity of which is the strongest. This anticyclonic circulation is not maintained solely by the heating in the equatorial latitudes but also by the topographical effect of the Tibetan Plateau as demonstrated by Tokioka and Noda (1985).

The westerlies over the equator at around $150^{\circ} \mathrm{W}$ to $120^{\circ} \mathrm{W}$ and $50^{\circ} \mathrm{W}$ to $20^{\circ} \mathrm{W}$ are very clear in the model. This is considered also as a part of characteristic responses of the equatorial atmosphere to the localized heating (forced Kelvin wave structure) as discussed by Lau and Lim (1984). Tokioka and Noda (1985) also shows that the equatorial westerlies at 


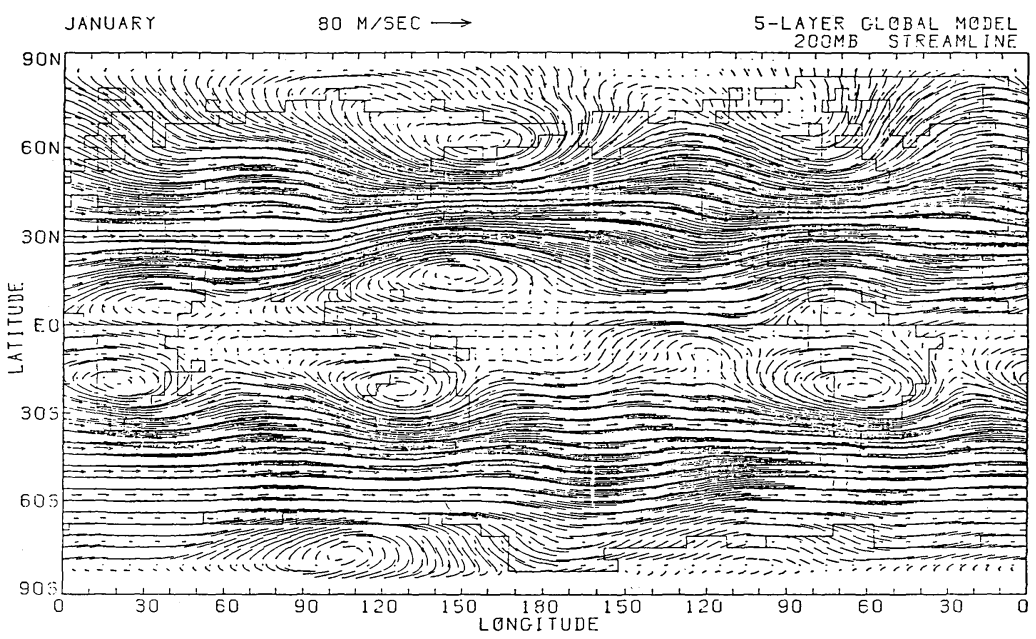

(a)

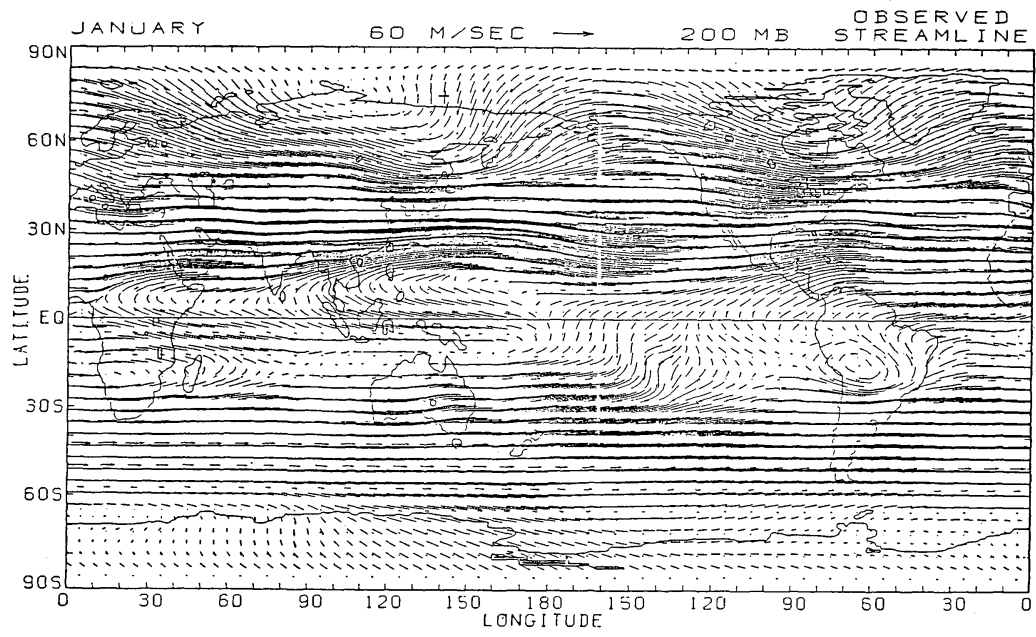

(b)

Fig. 17 Streamlines for the monthly averaged flows at $200 \mathrm{mb}$ for January. (a) model, (b) climatological map based on data analyzed by Oort (1983).

those longitudes are influenced little by the removal of the Tibetan Plateau, suggesting the importance of the localized heating in the winter monsoon area for maintaining the equatorial westerly over the east Pacific. Although a pair of anticyclones in the equatorial zone is not organized well in the climatological map, Kanamitsu (1981) and Bengtsson et al. (1982) have analized a flow field for FGGE's January, which is closer to the present model.

If we compare the flows over the North Pacific and the North Atlantic between Fig. 17 and 16 in the subtropics, flows in the eastern part of the oceans are contrasted to those in the western part of them. Flow is anticyclonic at $900 \mathrm{mb}$ and cyclonic at $200 \mathrm{mb}$ in the eastern part. This is consistent with the prevailed sinking motion in that area (see trough of the velocity potential field in Fig. 18). In the western part, flow is anticyclonic throughout the troposphere. The anticyclonic flow in the upper part is maintained as explained above, while the advection of vorticity is important for the maintenance of the low level anticyclonic flow. 
Non-zonal feature is dominant in the extratropical latitudes in the northern hemisphere, where we see an intensification of westerly jet at approximately northern part of each subtropical anticyclone. The intensification of jet is helped by large-scale topography as demonstrated by Tokioka and Noda (1985). With the increase of latitudes, the pattern of wavenumber two shows up gradually. In the southern hemisphere, flows tend to be zonal with increasing latitudes except over the Antarctica where the pattern of wavenumber one and two emerges.

Overall patterns of the streamlines are compared favorably with the climatological map. However, the flow speed is exaggerated in the model in the extratropical latitudes. The intensity of the stationary wave is also exaggerated in the model. The kinetic energy of the stationary wave is 9.6 $\mathrm{J} / \mathrm{Kg}$ when averaged in the entire northern hemisphere of the model below $100 \mathrm{mb}$, while it is $7.8 \mathrm{~J} / \mathrm{Kg}$ in Oort and Rasmusson (1971). This defect will be related indirectly to the too cold temperature in the upper part of the high latitudes, which provides a favorable condition for the amplification of stationary waves because of the low static stability.

Fig. 18 shows the velocity potential and the divergent wind vector at $200 \mathrm{mb}$ for the

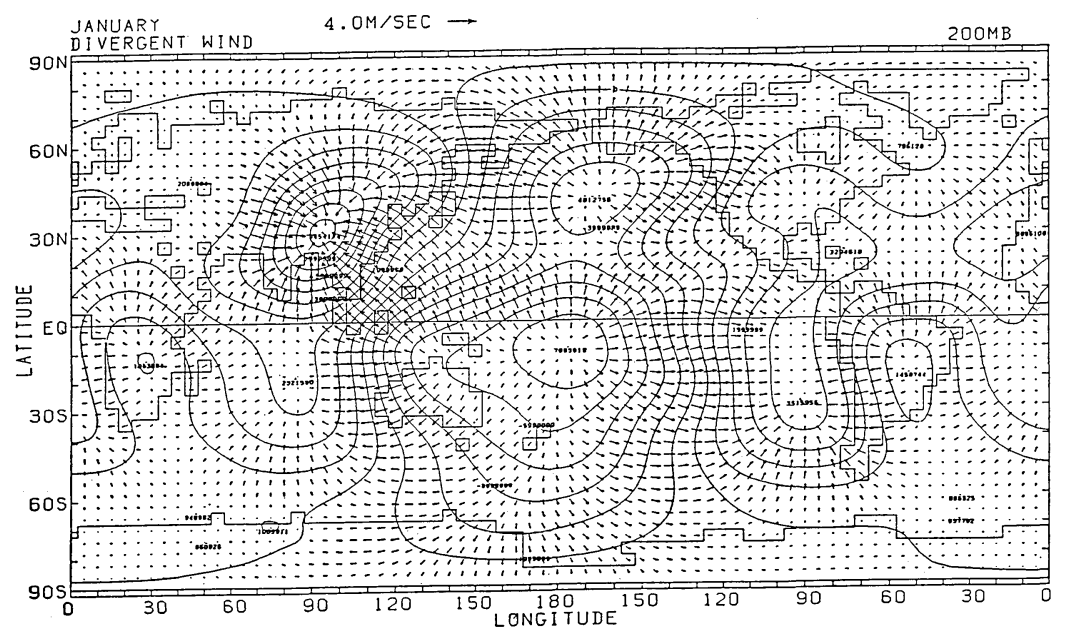

(a)

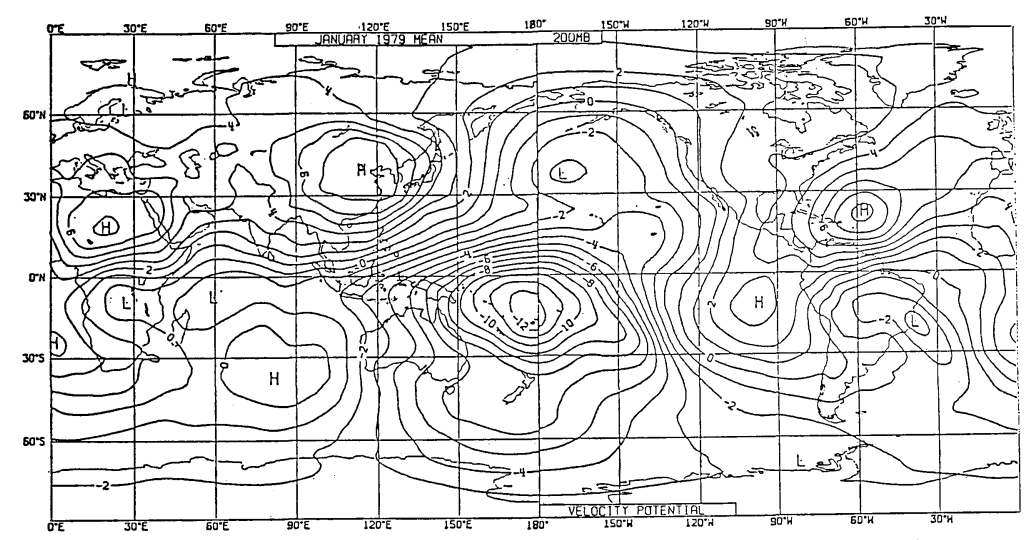

(b)

Fig. 18 Velocity potential and divergent wind velocity for the monthly averaged flows at $200 \mathrm{mb}$ for January. (a) model, (b) January 1979, analyzed by Kanamitsu (1981). Contour interval of velocity potential is $10^{6} \mathrm{~m}^{2} / \mathrm{s}$. 
model together with the map obtained by Kanamitsu (1981) for the FGGE's January at the same level. Overall correspondence is quite good between them. The maximum intensity of the divergent wind at this level is as much as $4 \mathrm{~m} / \mathrm{s}$.

Three centers of the divergence are found in the low latitudes both in the model and the FGGE's case. Those centers correspond well with the precipitation map (Fig. 7 (a)) and the total heating (Fig. 9). The minimum points of the velocity potential do not necessarily correspond to the peak of the precipitation but roughly to a weighted mean center of precipitation. Two centers of divergent motion are found for the negative velocity potential over the central Pacific, one of them over the north Australia and the other near the dateline at $10^{\circ} \mathrm{S}$. The latter center is closely connected with excessive precipitation over the equatorial Central Pacific.

Dominant westerlies are found over the equatorial eastern Pacific; and easterlies between Indonesia and Australia and over the western part of the South America. The cross equatorial component of the divergent wind is directed mostly northward. Strong southerlies exist in the winter monsoon area and over the South America.

In the extratropics we find a dominant divergent center over the North Pacific. The center is located to the south-east side of the surface low (i.e. the Aleutian low). Intense southerly outflows exist in the northern flank of the center, contributing to form the zonally averaged direct cell in high latitudes (see Fig. 21). The counterpart of this center is found in Fig. 18 (b) at a similar position with a comparable intensity.

The strongest convergent center is located over the eastern part of the Himalaya. Convergent flows come to the center from all direction, among which south-easterly from the winter monsoon area is the strongest. This picture has been noted by Blackmon et al. (1977) and Murakami and Unninayar (1977) as one of the basic features of the winter monsoon and as an important mechanism to accelerate a subtropical jet over the southern periphery of Japan.
In the southern hemisphere exist three centers of convergence over the eastern part of the three oceans around $20^{\circ} \mathrm{S}$. Systematic southerly is directed toward each center, contributing to the formation of the upper branch of the indirect (Ferrel) cell (see Fig. 21). Situations are slightly complicated in the northern hemisphere. However, we can find a similar feature (i.e. northerly over the eastern part of the Pacific and the Atlantic) in the middle latitudes.

\subsection{Zonally averaged velocity fields}

Zonally averaged zonal velocity is shown in Fig, 19 together with the observed climatology. Equatorial easterly is positioned well in the model. However, the width of the easterly zone is slightly wider than that in the climatological map. There are two peaks near the surface corresponding to the strong meridional wind of the Hadley circulation in each hemisphere. The intensity of of the surface easterly is too strong, a part of which is due to the strong easterly in the southern part of the Tibetan Plateau.

The tropospheric westerly jet is located at a reasonable latitude in each hemisphere. Model simulates a stronger jet in the nor-

(a)

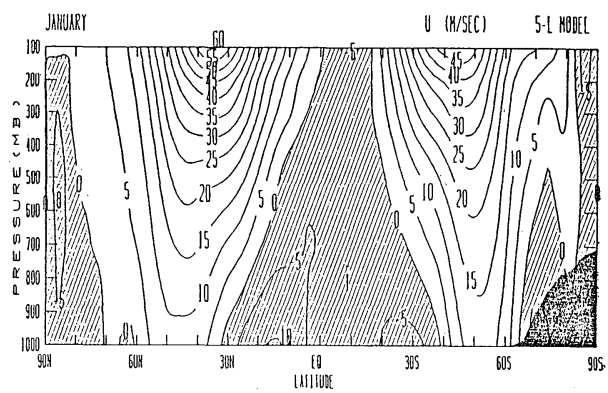

(b)

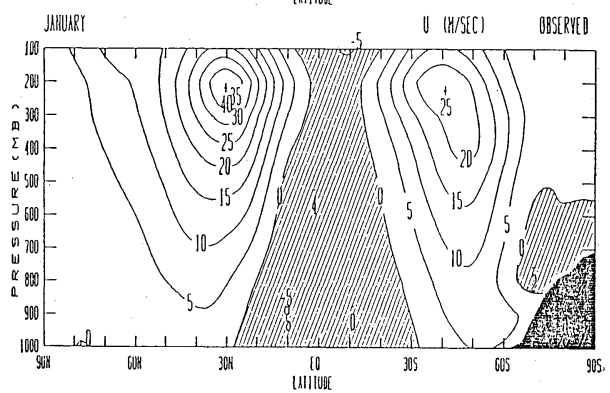

Fig. 19 Zonally and monthly averaged zonal wind for January (unit: $\mathrm{m} / \mathrm{s}$ ). (a) model, (b) climatological map. 
thern hemisphere than that in the southern hemisphere as is observed. However, the intensity is much stronger than the observed in both hemispheres in consistent with the excessively cold temperature in the upper part of the polar regions. This feature is commonly seen in other simulations reported so far except the one by Pitcher et al. (1983). In polar regions, there is an easterly zone in the model. This is consistent with a high pressure there and again consistent with too cold temperature at the upper level.

Fig. 20 shows the latitudinal distribution of the angular momentum source for both the model and the climatology. Solid and dashed lines indicate the surface frictional torque and the mountain torque for the model, and square and star the respective quantity for the climatological analyses compiled by Newton (1972). Agreement is good. There are two peaks of surface frictional torque in low latitudes. The latitudes of them coincide with those of low level easterly maxima in Fig. 19 (a). The minimum in the frictional torque near the equator is due to the low level local westerlies in that latitudes. The minimum in the model is almost zero, while it is still positive in the climatology. This suggests too strong westerlies in the model over the South America (see Fig. 16 (a)) probably due to the insufficient height of the model Andes around the equator, which will be otherwise efficient in reducing westerlies over the South America.

There is a negative peak of the frictional

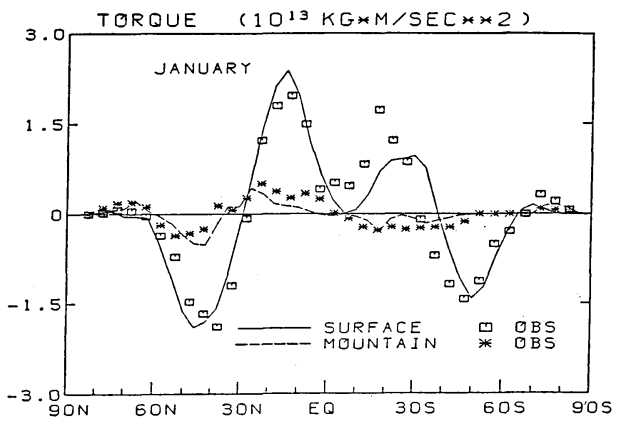

Fig. 20 Zonally and monthly averaged source of angular momentum for January (unit: $10^{13} \mathrm{~kg}$. $\mathrm{m} / \mathrm{s}^{2}$ ). Climatological values are taken from Newton (1972). torque in the middle latitudes of each hemisphere. The absolute value is larger in the northern hemisphere though the surface westerly is weaker than that in the southern hemisphere. The representative surface roughness length in the northern hemisphere is larger than that in the southern hemisphere as the land covers larger portion in that hemisphere. This will explain the feature mentioned above.

The intensity of the mountain torque is small compared to that of the frictional torque. The change of the sign of the mountain torque with latitude is simulated well confirming the reasonable distribution of the surface pressure indirectly.

The mean meridional mass flux is shown in Fig. 21 together with the observed data analysis. Mean meridional circulations show a three cell structure. There is a pronounced mass flux associated with the Hadley branch in the winter (northern) hemisphere. However, the intensity of this cell is less than

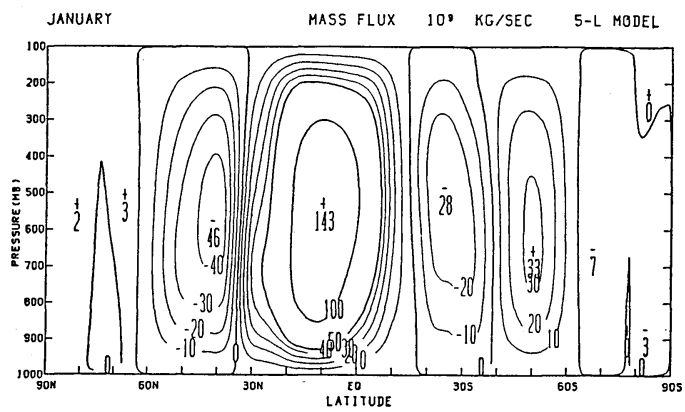

(a)

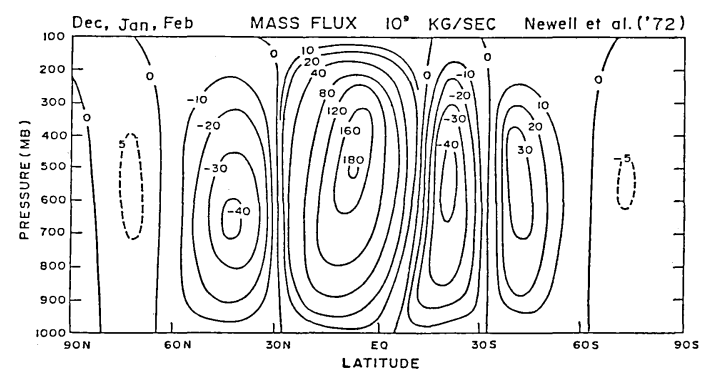

(b)

Fig. 21 (a) Zonally and monthly averaged meridional mass flux produced by the model for January (unit: $10^{9} \mathrm{~kg} / \mathrm{s}$ ), and (b) the corresponding climatological flux obtained for December through February by Newell et al. (1972). 
that of the climatology although the climatological value itself still has some ambiguity. This may be partially caused by the too low position of the upper lid as mentioned already in section 3.5. The increase of horizontal resolution may also increase the mass flux of the Hadley circulation further by organizing much confined rain belts in low latitudes.

\section{Penetrative cumulus effects in the model atmosphere}

\subsection{Thermodynamical effects}

Parameterization of penetrative cumulus convections is based on Arakawa-Schubert model (1974). Precipitation produced by the cumulus model is already shown in Fig. 8. Cumulus precipitation is produced mainly in the tropical region $\left(20^{\circ} \mathrm{N}-30^{\circ} \mathrm{S}\right)$. Compared with the total precipitation in Fig. 7 , it is noted that most of the precipitation in the tropics is due to penetrative cumulus convections, in agreement with the commonly accepted view.

Fig. 22 shows the zonally averaged cloud base mass flux as a function of the cloud top. Bi-modal structure noted by Yanai et al. (1976) is confirmed in the tropical latitudes. Peaks are located approximately at $300 \mathrm{mb}$ and $900 \mathrm{mb}$. It is interesting to note that the peaks of deep cloud mass flux at $5^{\circ} \mathrm{N}$ and $15^{\circ} \mathrm{S}$ are located at latitudes in between those of the peaks of shallow cloud mass flux. Dominant mass flux of shallow cumulus is found in the subtropical latitudes, and a minor one around $50^{\circ} \mathrm{N}$.

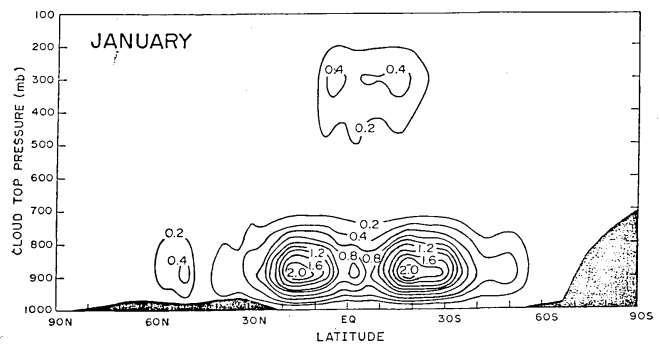

Fig. 22 Zonally and monthly averaged distribution of cloud base mass flux of penetrative cumulus convection produced by the model for January (unit: $\mathrm{mb} / \mathrm{hr}$ ). The ordinate indicates the level where the model cumulus detrains.
The vertical profile of the cloud base mass flux distribution in equatorial regions may further be compared with that derived by Yanai et al. (1976), although the analyses have been made for the localized data around Marshall Islands from 15 April through 22 July, 1956. The result is reproduced in Fig. 23. We do not go into quantitative comparisons because of the differences both in averaging area and period. Qualitatively, bimodal structure is basically reproduced in the model as mentioned above. However, if we compare the ratio of cloud base mass fiux between the deep and the shallow cumuli in ITCZ latitudes, the present model

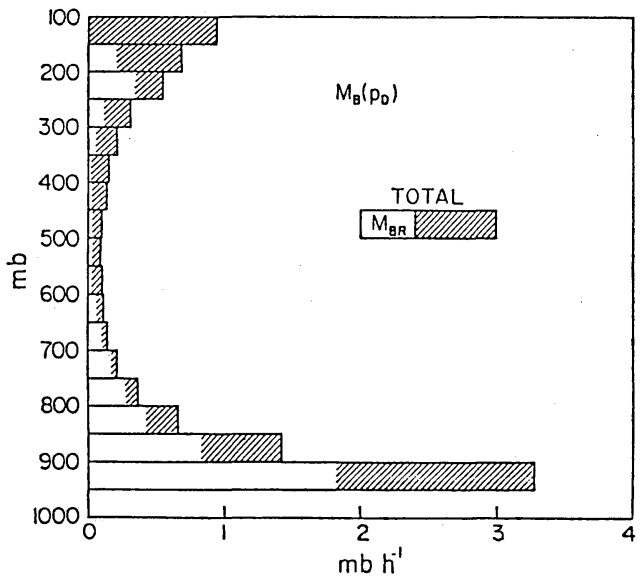

Fig. 23 Cloud base mass flux distribution analyzed by Yanai et al. (1976) for the Marshall Islands for the period of 15 April through 22 July, 1956.

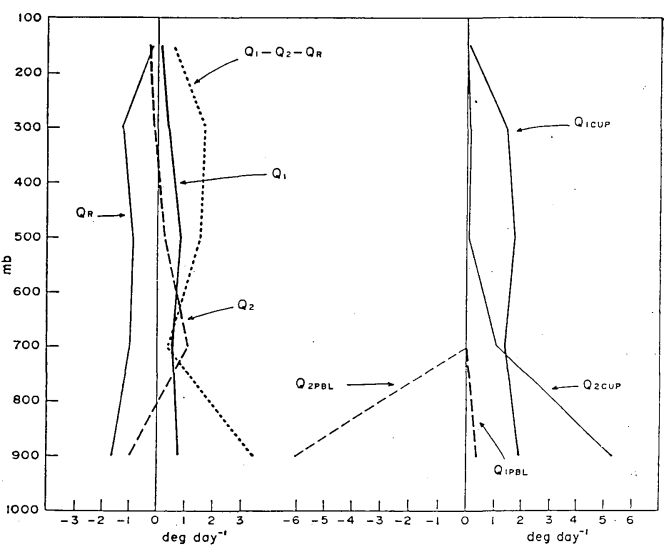

Fig. 24 Vertical distribution of heat source $Q_{1}$ and moisture $\operatorname{sink} Q_{2}$ produced by the model for the latitude between $10^{\circ} \mathrm{N}$ and $20^{\circ} \mathrm{S}$ (unit : $\mathrm{K} / \mathrm{d})$. 
underestimates the mass flux associated with the shallow one.

Fig. 24 shows the apparent heat source $Q_{1}$ and moisture sink $Q_{2}$ obtained for the zone between $10^{\circ} \mathrm{N}$ and $20^{\circ} \mathrm{S}$. Definitions of $Q_{1}$ and $Q_{2}$ just follow the ones defined in Yanai et al. (1973). $Q_{1}$ is decomposed into five parts in the model;

$$
Q_{1}=Q_{1 \mathrm{CUP}}+Q_{1 \mathrm{PBL}}+Q_{R}+Q_{1 \mathrm{LSC}}+Q_{1 \mathrm{MLC}}
$$

where $Q_{1 \text { cup }}$ is the heating due to penetrative cumulus convection through the cumulus induced subsidence, $Q_{1 \mathrm{PBL}}$ the heating due to sensible heat flux convergence within the PBL, $Q_{R}$ the heating due to radiation, $Q_{1 L S C}$ the heating due to large-scale condensation and $Q_{1 \mathrm{MLC}}$ the heating due to middle level convection. As the latter two are small in these latitudes, they are not shown.

$Q_{2}$ is decomposed into four parts ;

$$
Q_{2}=Q_{2 \mathrm{CUP}}+Q_{2 \mathrm{PBL}}+Q_{2 \mathrm{LSC}}+Q_{2 \mathrm{MLC}}
$$

where $Q_{2 \text { CuP }}$ is the drying effect of penetrative cumulus convection through the cumulus induced subsidence, $-Q_{2 \mathrm{PBL}}$ the moistening effect through the vertical flux convergence within the PBL, $Q_{2 \mathrm{LSC}}$ the drying effect of large-scale condensation and $Q_{2 \mathrm{MLC}}$ the drying effect of middle level convection. The latter two are small and are not shown here.

The sub-grid-scale source term in the moist static energy budget is given by

$$
\begin{aligned}
Q_{1}-Q_{2}-Q_{R} \fallingdotseq & \left(Q_{1 \mathrm{CUP}}-Q_{2 \mathrm{CUP}}\right) \\
& +\left(Q_{1 \mathrm{PBL}}-Q_{2 \mathrm{PBL}}\right) .
\end{aligned}
$$

( $\left.Q_{1 \mathrm{CUP}}-Q_{2 \mathrm{CUP}}\right)$ changes its sign at around $700 \mathrm{mb}$, i.e. negative below that level and positive above that level. This clearly demonstrates the upward transport of moist static energy by the parameterized cumulus. Turbulence within the PBL provides a pronounced positive source $\left(Q_{1 \mathrm{PBL}}-Q_{2 \mathrm{PBL}}\right)$ below $700 \mathrm{mb}$. The combined effects of both of them approximately determine $\left(Q_{1}-Q_{2}-Q_{R}\right)$. $\left(Q_{1}-Q_{2}-Q_{R}\right)$ is positive throughout the layer, and has two peaks, one at around $300 \mathrm{mb}$ and the other near the surface. The former peak is primarily due to the deep cumulus and

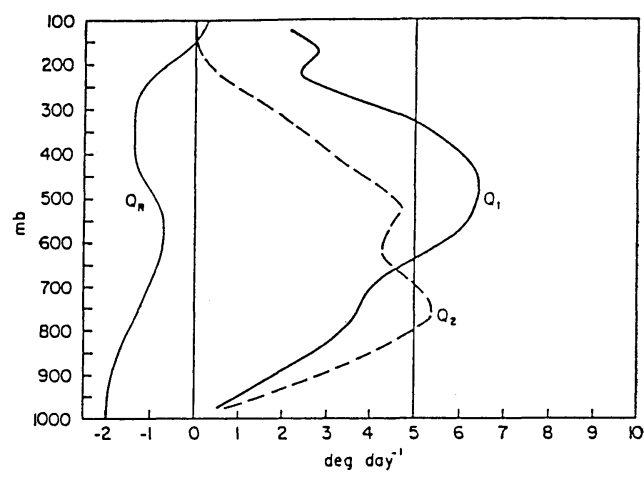

Fig. 25 Vertical distribution of heat source $Q_{1}$ and moisture sink $Q_{2}$ analyzed by Yanai et al. (1973) for the Marshall Islandds for the period of 15 April through 22 July, 1956 (unit: K/d).

the latter to the turbulence within the PBL.

The vertical profile of $Q_{1}, Q_{2}$ and $Q_{R}$ used to derive the cloud base mass flux distribution of Fig. 23 is shown in Fig. 25. As the analyses are made in the layer above the PBL, $Q_{1 \mathrm{PBL}}$ and $Q_{2 \mathrm{PBL}}$ are identically zero in this case. The values of both $Q_{1}$ and $Q_{2}$ are about five times as large as the present ones. Reminding that both $Q_{1 \mathrm{PBL}}$ and $Q_{2 \text { PBL }}$ are zero in Yanai et al. (1973), we compare $Q_{1 \text { CUP }}$ and $Q_{2 \text { CUP }}$ in the present case with $\left(Q_{1}-Q_{R}\right)$ and $Q_{2}$ in Yanai et al. (1973), respectively. Apart from the values themselves, we notice systematic differences in the vertical profiles between them. In Yanai et al. (1973), both $\left(Q_{1}-Q_{R}\right)$ and $Q_{2}$ decrease with the decrease in height in the lower part of the atmosphere, while opposite is rue in the present case. In another words, the parameterized cumulus tends to heat and dry the lower part of the free atmosphere too much. Lord (1982) also showed the excessive drying effect of the ArakawaSchubert cumulus parameterization under the situation of GATE Phase III. We noted above that the cloud base mass flux for the shallow cumulus is relatively small in the present model compared to that for the deep one. Usually shallow cumulus has evaporative moistening and cooling effects in the lower part. Therefore the differences noted with respect to $Q_{1 \text { CUP }}$ and $Q_{2 \text { CuP }}$ are internally consistent with the difference noted with respect to the distribution of cloud 
base mass flux.

The present cumulus model seems to give less cloud base mass flux for shallow cumulus. We obtained this conclusion from the comparison of the model results, which is averaged over the entire area between $20^{\circ} \mathrm{S}$ and $10^{\circ} \mathrm{N}$, with the Marshall Islands' case which is obtained for a limited interval of time. However, we do not consider the present conclusion depends on the locality of Marshall Islands nor on the special period adopted for the analyses. We have done a similar comparison for the model data, averaged over several grids corresponding to Marshall Islands for the time interval from 15 April to 22 July, and confirmed the same results (Tokioka et al. 1984).

We mentioned in section 3.6 that the mixing ratio of water vapor is less in the lower part of the model tropics by as much as $2 \mathrm{~g} / \mathrm{kg}$ compared to the climatological value. This seems to be closely connected with shortcomings of the cumulus model. Some discussions will be found in section 6 in this respect.

\subsection{Dynamical effects}

The redistribution of momentum by penetrative cumulus convection is parameterized in a similar way as is done for the thermodynamic quantities, with the use of the cumulus mass flux derived from the ArakawaSchubert theory. For details, see Arakawa and Mintz (1974) or Tokioka et al. (1984). In order to clarify the role of cumulus redistribution of momentum, budget of the zonally averaged zonal momentum is obtained in the equatorial latitudes. Figs. 26 (a) through (c)

Fig. 26 Zonally and monthly averaged zonal momentum budget of the model. $u, v$ and $\omega$ indicate eastward wind, northward wind and vertical $p$-velocity, respectively; $f$, Coriolis factor; $a$, radius of the earth; $\left(^{-}\right)$, time average; ('), deviation from time average; [ ], zonal average. $F^{U}$ indicates the sum of zonal momentum acceleration by sub-grid-scale processes, i.e. turbulent flux convergence within the planetary boundary layer $F_{P B L}^{U}$, redistribution of momentum by penetrative cumulus convection $F^{U} C U P$ and sub-grid-scale horizontal diffusion $F_{H D}^{U}$. and (c) $18^{\circ} \mathrm{N}$. show the results at $10^{\circ} \mathrm{S}, 2^{\circ} \mathrm{N}$ and $18^{\circ} \mathrm{N}$, respectively, where $\left(^{-}\right)$and ( )' indicate time average and deviation from it and [ ] the zonal average. $u$ and $v$ are velocity components in the eastward and northward directions, $\omega$ the vertical $p$-velocity, $f$ the Coriolis factor, a the radius of the earth, and

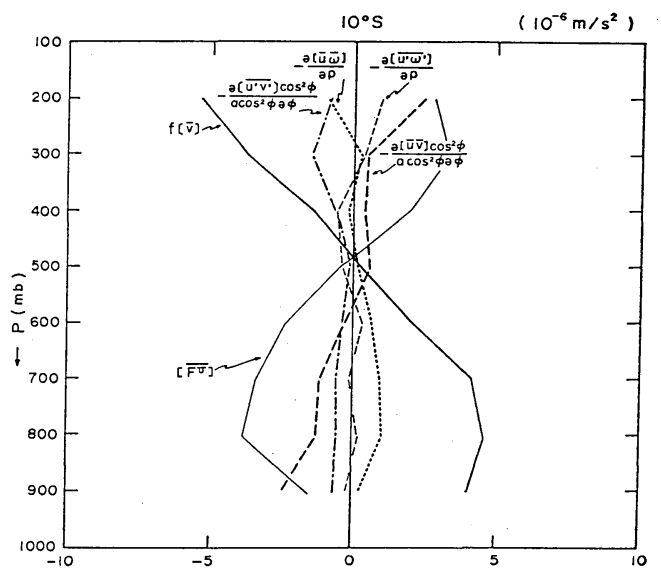

(a)

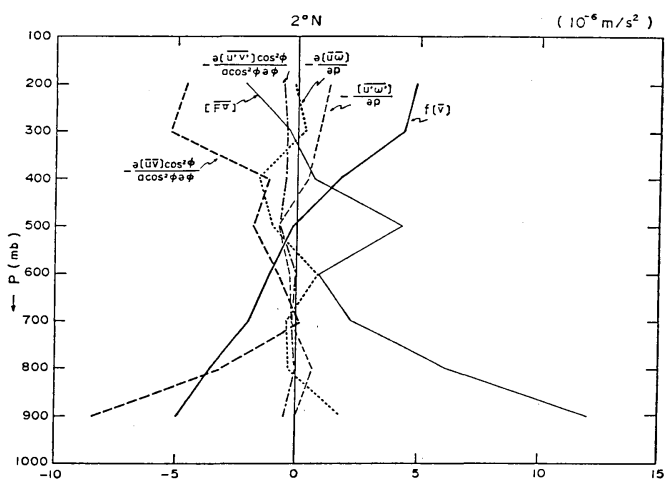

(b)

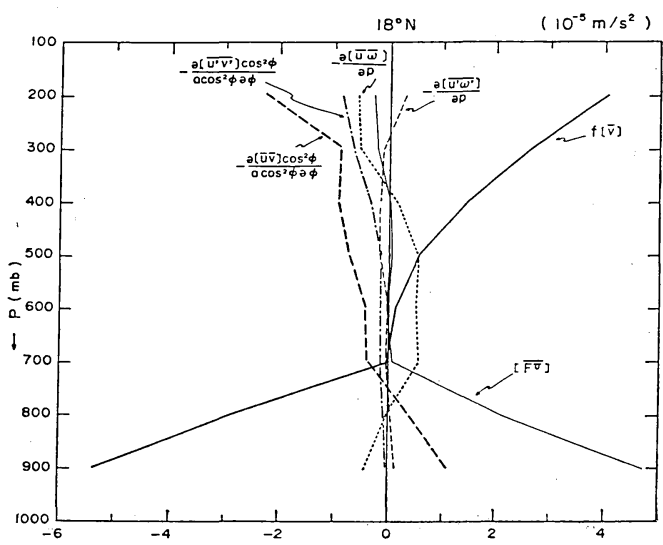

(c) 


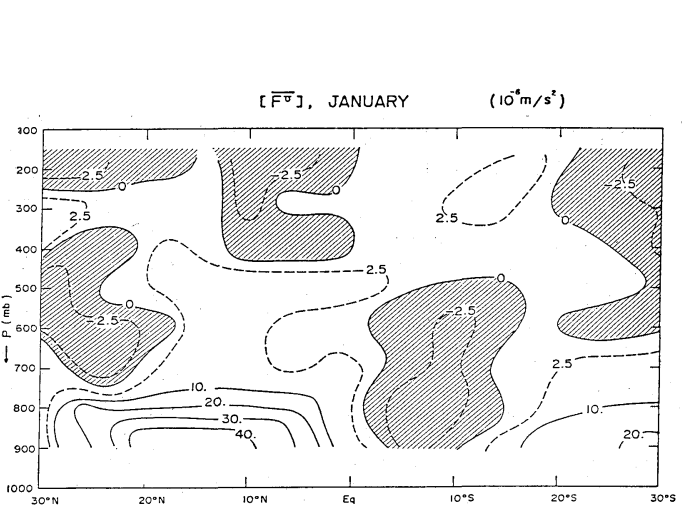

(a)

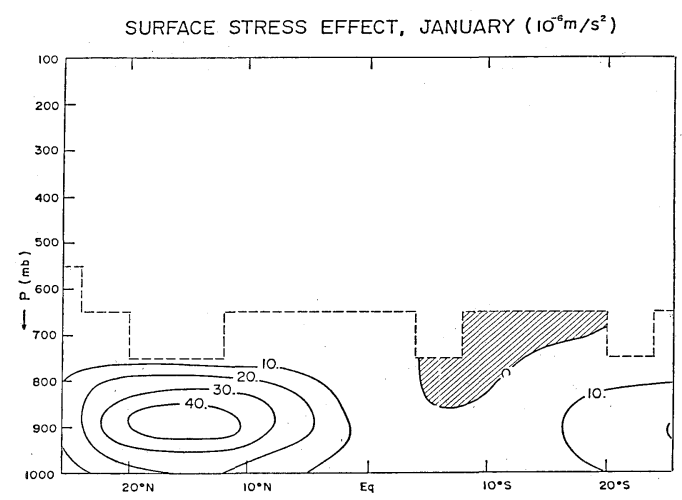

(c)

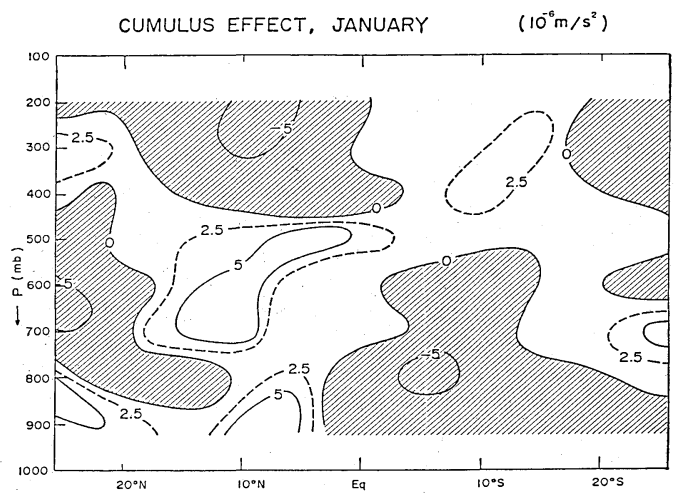

(b)

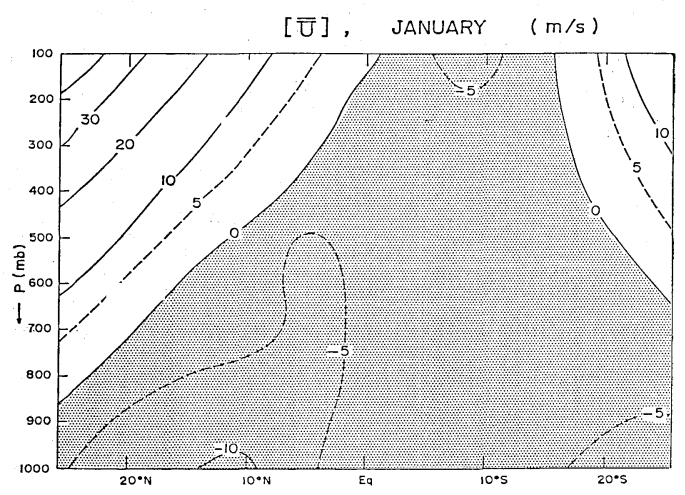

(d)

Fig. 27 (a) Zonally and monthly averaged distribution of $F^{U}$ (unit: $10^{-6} \mathrm{~m} / \mathrm{s}^{2}$ ). (b) Zonally and monthly averaged distribution of acceleration of zonal momentum by penetrative cumulus convection, $F_{C U P}^{U}$ (unit : $10^{-6} \mathrm{~m} / \mathrm{s}^{2}$ ). (c) Zonally and monthly averaged distribution of acceleration of zonal momentum by turbulence within the $P B L, F_{P B L}^{U}$ (unit: $10^{-6} \mathrm{~m} / \mathrm{s}^{2}$ ). (d) Zonally and monthly averaged distribution of zonal wind (unit: $\mathrm{m} / \mathrm{s}$ ).

$\varphi$ the latitude. $F^{U}$ is the sum of the effects of cumulus redistribution $F_{\text {cUp }}^{U}$, flux convergence of zonal momentum by turbulent motions within the PBL (or simply termed as surface stress effect) $F_{\mathrm{PBL}}^{U}$, horizontal subgrid-scale diffusion $F_{\mathrm{HD}}^{U}$ and the form drag $F_{\mathrm{FD}}^{U}$. The zonally averaged distributions of $F^{U}, F_{\mathrm{CUP}}^{U}, F_{\mathrm{PBL}}^{U}$ together with that of $u$ are shown in Fig. 27 (a) through (d). As the effects of $F_{\mathrm{HD}}^{U}$ the $F_{\mathrm{FD}}^{U}$ are small in low latitudes compared with the others, they are not shown.

At $10^{\circ} \mathrm{S}$ (Fig. 26 (a)), the balance is maintained mostly between $f[\bar{v}]$ and $\left[\bar{F}^{U}\right]$. As the effect of surface stress is small at this latitude (Fig. 27 (c)), most of $\left[\bar{F}^{U}\right]$ is due to the cumulus effect. Therefore cumulus effect is very important at this la- titude. Cumulus effect change its sign at around $500 \mathrm{mb}$, namely negative in the lower part and positive in the upper half. Considering that the vertical wind shear is easterly at $10^{\circ} \mathrm{S}$ (Fig. $27(\mathrm{~d})$ ), we may say that the penetrative cumuli have an effect of simple vertical mixing of zonal momentum at this latitude.

At $2^{\circ} \mathrm{N}$, the horizontal flux convergence by stationary flows is also important besides $\left[\bar{F}^{U}\right]$ and $f[\bar{v}]$. It is interesting to note that the Coriolis term is still important at this latitude for the zonally averaged zonal momentum budget. Most part of $\left[\bar{F}^{U}\right]$ below $800 \mathrm{mb}$ is explained by the surface stress effect (Fig. 27 (c)), while it is explained by the cumulus effect above that level (Fig. 27 (b)). The vertical profile of cumulus effect 
is slightly complicated here reflecting not a simple vertical wind shear.

At $18^{\circ} \mathrm{N}$ below $700 \mathrm{mb}$, the balance is maintained between $f[\bar{v}]$ and $\left[\bar{F}^{U}\right] .\left[\bar{F}^{U}\right]$ is mostly due to the surface stress effect (Fig. 27 (c)). At the upper level the Coriolis term is balanced by a combination of several flux convergence terms.

Cumulus effect on the zonal momentum (Fig. 27 (b)) has a rather systematic structure in the meridional plane. The rising center of the Hadley circulation exists at around $10^{\circ} \mathrm{S}$. Therefore the cumulus effect helps to enhance Hadley circulation, especially in its northern branch, through the $-f[\bar{u}]$ term. Present results confirm the ones noted by Stone et al. (1974) and Helfand (1979) in GISS.GCM.

\section{Discussion and conclusions}

As repeatedly mentioned so far, one of the poor performances of the present simulation is that of the Siberian high and the associated circulations. We recognize this most clearly in the $900 \mathrm{mb}$ streamline map (Fig. 16). There is a strong northerly along the eastern periphery of China in the model. Easterly found in the southern portion of the Tibetan Plateau is also too strong. In the climatological map, no strong northerly is found over the eastern part of China, but a weak westerly. If the intensity of the northerly that comes down around the northeast corner of the Tibetan Plateau would be much less in the model, the flow pattern would be much closer to the observed one.

In the present model with $5^{\circ}$ longitude by $4^{\circ}$ latitude resolution, details of the topography are wiped out in the smoothing process. We find out systematic mountain range above $1,000 \mathrm{~m}$, such as Yablonoi Mts., Ta Hingam Ling, Stanovoi Mts. etc., in the north-east corner of the Plateau, which are considered to be effective in blocking northerly in the eastern part of China. Those mountain ranges are absent in the model topography. Too strong easterly in the southern part of the Plateau, excessive evaporation in the Bay of Bengal due to cold and dry easterly and possibly excessive down- wind rainfall over the equatorial Indian Ocean, all of these shortcomings of the present simulation may be improved if only the cold northerly is shut off in some way. Model topography in the Indochina peninsula may also be responsible for the too strong easterly.

It is our impression that small scall mountain ranges are important in determining low lovel flows and thus the heating distribution because the low level flow influences the air mass transformation over the warm ocean. It is interesting to note that the defect mentioned above is not seen in the results obtained from the two-level models, such as Mintz et al. (1972) and Gates and Schlesinger (1977). Surface drag coefficient in those two-level models is a function of elevation (Arakawa, 1972; Gates et al. 1971) and is similar to the Cressman drag (Cressman, 1960). While, in the present model the drag coefficient is determined only with local information of the PBL structure. No information about subgrid-scale topographies is included in the drag coefficient. This difference seems to be essential in understanding the poor simulation of the Siberian high in the present model compared to those in two-level models. Subgrid-scale topographies will effectively reduce the strong anticyclonic flows around the Tibetan Plateau.

On the revising stage of this paper, we noticed papers by Boer et al. (1984 a, b) and the work by Sumi (1985). Boer et al. (1984 a, b) performed a simulation with the Cressman drag. The Siberian high is reproduced well in their simulation. This supports our speculation stated above, although not much is discussed about it by the authors. Sumi (1985) also noticed the importance of the subgrid-scale topographies through the numerical simulation of cold surges around the Tibetan Plateau. He has suggested the use of the drag coefficient which includes the terms proportional to the standard deviation of subgrid-scale topographies. He has modified also a coefficient of vertical eddy diffusions in a similar way. Probably further studies may be needed on the parameterization of sub-grid-scale topographies. 
The lack of the northward bulge of the Siberian high (see Fig. 15 (a)) is noted in the present simulation. This may also be related with processes discussed above. Another possibility may be ascribed to the too low elevation of Ural Mts. in the present model, which may have some effective role, as a barrier, in shutting off warm flow from the west and in storing cold air over the Siberian plain.

The north-eastward shift and the excessive deepening of the Aleutian low are also commonly observed in the simulation by Manabe et al. (1979), Gilchrist (1979), Boer and McFarlane (1979), Manabe and Hahn (1981) etc.. This may possibly be linked with the poor simulation of the Siberian high. Surface energy flux might be exaggerated in the area off the east coast of Siberia, although we do not have data to verify this speculation yet.

Excessive development of the Aleutian low may not be independent of the low static stability of the troposphere in the polar regions of the model due to the too cold upper atmosphere (Fig. 11). The low static stability offers a favorable condition for the development of cyclones. The decrease of the static stability is pronounced especially over the area from Alaska to the north-west of Canada (Fig. 12). The cyclonic activity is actually large in that area. This helps to shift the center of the low toward the north-east direction and to extend low pressure zone toward the northwest part of Canada, besides the overall excessive deepening of the pressure in the wide area in discussion. As clarification of causes and results from only a single experiment is limited, further studies on this will also be necessary.

Tokioka (1985) studied the characteristics of the long term variations of the present model atmosphere under the perpetual January condition. He shows that the variance of the 30-day averaged sea level pressure has a maximum in the north-western part of Canada and not in the Alaska Bay where the climatological maximum is located. This is not surprising if we consider the less stable static stability in that area in the present model.

We mentioned, with respect to Fig. 5, that the cloudiness in high latitudes is over the climatological value. This may also be interrelated with the less stable static stability there.

The overall performance of the model is good in low latutudes. However, there are some differences in the precipitation over the Central Pacific both near the equator and in the southern hemisphere. There is a minimum of velocity potential at $200 \mathrm{mb}$ over the western part of the equatorial Pacific (Fig. 18). The minimum extends to the dateline. This feature is closer to the situation in FGGE January (Sumi and Murakami, 1981) rather than to that presented by Murakami and Unninayar (1977) or Krishnamurti et al. (1973). There was a minor warming of SST in the equatorial Central Pacific in FGGE's January, although it is not identified as $\mathrm{El}$ Niño event. The reason why the climate of the present model is like that in a weak El Niño is not clear. One of the possible causes for this may be ascribed to the too strong anticyclonic flow around the Tibetan Plateau, again. Excessive rainfall over the equatorial Indian Ocean, caused by the anticyclonic flow, may reduce the rainfall over the maritime continent probably through the subsidence of induced east-west circulation. The reduction of rainfall in the maritime continent may help to increase the rainfall over the equatorial Central Pacific in a similar mechanism.

The cumulus parameterization based on Arakawa and Shubert's (1974) theory gives a systematic distribution of cumulus precipitation in low latitudes. Bi-modal structure is realized there in the vertical distribution of cloud base mass flux. Budget analyses of heat and moisture, however, show that the moistening and cooling effects are underestimated in the lower part of the free atmosphere. This may be due to the underestimate of the mass flux of shallow cumulus. If the cloud base mass flux of shallow cumulus increases relatively to that of deep one, the mixing ratio of water vapor will increase in the lower part of the tropical 
atmosphere. We can, however, see the drawback from another viewpoint, i.e., the deep cloud overestimates the drying and warming effects in the lower part of the free atmosphere. If we stand on this viewpoint, inclusion of precipitation downdrafts in cumulus into the Arakawa-Schubert model is a promising candidate for improving the performance of the model. Diagnostic studies by Johnson (1976) and Nitta (1977, 1978) show that excessive mass flux of shallow cumulus is needed to moisten and cool the lower layer when precipitation downdrafts are neglected. Since precipitation downdrafts act to moisten and cool the lower troposphere, the thermal structure on the model tropics will be improved by the inclusion of the downdrafts without a significant increase of the mass flux of shallow cumulus.

Conclusions from the present study are summarized as follows :

1) The model has succeeded in reproducing basic characteristic features of January circulations in the troposphere. Simulations are especially good in the tropics.

2) There are systematic disagreements between the model. and the climatology in the vicinity of the Tibetan Plateau. Northerly is too strong near the surface along the eastern coast of China, and easterly is also strong in the southern periphery of the Plateau. This anticyclonic flow is cold and dry, and causes enhanced evaporation in the Bay of Bengal and enhanced precipitation over the equatorial Indian Ocean. This, together with the comparisons of simulations presented so far, suggests the underestimate of dissipative effects by sub-grid-scale topographies in the present model.

3) The Aleutian low is too deep and is shifted to the north-eastward direction from its climatological position. Low static stability area corresponds to the area of excessive deepening well.

4) Temperature in polar regions of the upper troposphere is low, and thus provides low static stability there and excessive westerlies in the mid-latitudes of the upper troposphere.

5) Arakawa-Schubert parameterization is adopted for penetrative cumulus convection. Most of precipitation in low latitudes is due to the parameterized penetrative cumulus. This parameterization gives well organized precipitation. The budget analysis of heat and moisture shows that the present parameterization lacks in moistening and cooling effects at the lower levels. The budget analysis of zonally averaged zonal momentum shows that cumulus redistribution of zonal momentum is not negligible in low latitudes, especially in the vicinity of rising center of the Hadley circulation $\left(\sim 10^{\circ} \mathrm{S}\right)$. It contributes to intensily Hadley circulation through the Coriolis force.

\section{Acknowledgements}

The authors thank Prof. A. Arakawa of the UCLA for making the basic UCLA model available to them, and for providing some of the members opportunities to visit the UCLA. We also thank Dr. A. Katayama, the Meteorological college, for his encouragements throughout this work. Thanks are extended to Dr. M. Aihara, the head of the forecast research division of the MRI, and to Mr. T. Yoshida, Mr. H. Ito and Dr. E. Uchida, the former heads of the division, for their continuous encouragements and patience through this work. We also thank Miss H. Imai for drafting. Reviewers' comments were useful in revising the original manuscripts.

The numerical time integration of the model was made on the HITAC M- $200 \mathrm{H}$ computer of the MRI.

\section{Referencs}

Arakawa, A., 1972: Design of the UCLA general circulation model. Tech. Report No. 7, Department of Meteorology, University of California, Los Angeles, CA, $116 \mathrm{pp}$.

and Y. Mintz, 1974: The UCLA Atmospheric General Circulation Model, Notes distributed at the workshop 25 March-4 April 1974, UCLA.

and W.H. Schubert, 1974: Interaction of a cumulus cloud ensemble with the large-scale environment, Part I. J. Atmos. Sci., 31, 674-701. - and V.R. Lamb, 1977 : Computational design of the basic dynamical processes of the UCLA general circulation model. Methods in Computational Physics, Vol. 17 (Academic Press Inc., 
New York 1977), pp. 173-265.

Bengtsson, L., M. Kanamitsu, P. Källberg and S. Uppala, 1982: FGGE research activities at ECMWF. Bull. Am. Meteorol. Soc., 63, 277-303.

Blackmon, M. L., J. M. Wallace, N.-C. Lau and S. L. Mullen, 1977: An observed study of the northern hemisphere wintertime circulation. J. Atmos. Sci., 34, 1040-1053.

Boer, G. J. and N.A. McFarlane, 1979: The AES atmospheric general circulation model. Report of the JOC Study Conference on Climate Models : Performance, Intercomparison and Sensitivity Studies, Washington, DC, 3-7 April 1978. GARP Publ. Ser., No. 22, 409-460.

- - R. Laprise, J. D. Henderson and J.-P. Blanchet, 1984a: The Canadian Climate Center spectral atmospheric general circulation model. Atmosphere-Ocean, 22, 397-429.

- $\longrightarrow$ and 1 1984b: The climatology of the Canadian Climate Center general circulation model as obtained from a five-year simulation. Atmosphere-Ocean, 22, 430-473.

Corby, G. A., A. Gilchrist and P. R. Rowntree, 1977 : The U.K. Meteorological Office 5-level general circulation model. Methods in Computational Physics, Vol. 17 (Academic Press Inc., New York 1977), pp. 67-110.

Cressman, G.P., 1960: Improved terrain effects in barotropic forecasts. Mon. Wea. Rev., 88, 327342 .

Deardorff, J.W., 1972: Parameterization of the planetary boundary layer for use in general circulation models. Mon. Wea. Rev., 100, 93-106.

Dopplick, T.G., 1979: Radiative heating of the global atmosphere: Corrigendum. J. Atmos. Sci., 36, 1812-1817.

Gates, W.L., E.S. Batten, A. B. Kahle and A.B. Nelson, 1971: A documentation of the MintzArakawa two-level atmospheric general circulation model. R-877-ARPA, The Rand Corporation, Santa Monica, CA, 408 pp.

and M.E. Schlesinger, 1977: Numerical simulation of the January and July global climate with a two-level atmospheric model. J. Atmos. Sci., 34, 36-76.

Gilchrist, A., 1979: The Meteorological Office 5layer general circulation model. Report of the JOC Study Conference on Climate Models : Performance, Intercomparison and Sensitivity Studies, Washington, DC, 3-7 April 1978. GARP Publ. Ser., No. 22, 254-295.

Gill, A.E., 1980: Some simple solutions for heatinduced tropical circulation. Quart. J. Roy. Met. Soc., 106, 447-462.

Godbole, R. V. and J. Shukla, 1981: Global Analysis of January and July Sea Level Pressure. Laboratory for Atmospheric Sciences, Modeling and Simulation Facility, NASA Goddard Space Flight Center, Greenbelt, MD.

Helfand, H. M., 1979: The effect of cumulus fric- tion on the simulation of the January Hadley circulation by the GLAS model of the general circulation. J. Atmos. Sci., 36, 1827-1843.

Holloway, J. L., Jr. and S. Manabe, 1971: Simulation of climatology by a global general circulation model. Mon. Wea. Rev., 99, 335-370.

Hoskins, B. J. and D. J. Karoly, 1981: The steady linear response of a spherical atmosphere to thermal and orographic forcing. J. Atmos. Sci., 38, 1179-1196.

Johnson, R. H., 1976: The role of convective-scale precipitation downdrafts in cumulus and synopticscale interactions. J. Atmos. Sci., 33, 1890-1910.

Kanamitsu, M., 1981: Some climatological and energy budget calculations using the FGGE III-b analyses during 1979. Dynamic Meteorology: Data assimilation methods. Applied mathematical sciences; vol. 36, 263-318. L. Bengtsson, M. Ghil, E. Källen (eds.), Springer-Verlag New York, Inc.

Kasahara, A. and W. Washington, 1971: General circulation experiments with a six-layer NCAR model, including orography, cloudiness and surface temperature calculations. J. Atmos. Sci. 28, $657-701$.

- 1984: The linear response of a stratified global atmosphere to tropical thermal forcing. J. Atmos. Sci., 41, 2217-2237.

Katayama, A., 1972: A simplified scheme for computing radiative transfer in the troposphere. Tech. Report No. 6, Department of Meteorology, University of California, Los Angeles, CA, $77 \mathrm{pp}$.

Kitoh, A. and T. Tokioka, 1985: A simulation of the tropospheric general circulation with the MRI atmospheric general circulation model. Part II : The July performance. (To be submitted for publication)

Krishnamurti, T. N., M. Kanamitsu, W. J. Koss and J.D. Lee, 1973: Tropical east-west circulations during the northern winter. J. Atmos. Sci., 30, 780-787.

Lau, K.-M. and H. Lim, 1984: On the dynamics of equatorial forcing of climate teleconnections. $J$. Atmos. Sci., 41, 161-176.

Lord, S. J., 1982: Interaction of a cumulus cloud ensemble with the large-scale environment. Part III : Semi-implicit test of the Arakawa-Schubert cumulus parameterization. J. Atmos. Sci., 39, 88-103.

Manabe, S., J.L. Holloway, Jr. and H. M. Stone, 1970: Tropical circulation in a time-integration of a global model of the atmosphere. J. Atmos. Sci., 27, 580-613.

, D. G. Hahn and J. L. Holloway, Jr., 1974 : The seasonal variation of the tropical circulation as simulated by a global model of the atmosphere. J. Atmos. Sci., 31, 43-83.

and J. L. Holloway, Jr., 1975: The seasonal variation of the hydrologic cycle as simulated by a global model of the atmosphere. J. Geophys. 
Res., 80, 1617-1649.

D. G. Hahn and J.L. Holloway, Jr., 1979 : Climate simulations with GFDL spectral models of the atmosphere: Effect of spectral truncation. Report of the JOC Study Conference on Climate Models: Performance, Intercomparison and Sensitivity Studies, Washington, DC, 3-7 April 1978. GARP Publ. Ser., No. 22, 41-94.

- and 1981 : Simulation of atmospheric variability. Mon. Wea. Rev., 109, 22602286.

Matsuno, T., 1966: Quasi-geostrophic motions in the equatorial area. J. Meteor. Soc. Japan, 44, $25-43$.

McAvaney, B. J., W. Bourke and K. Puri, 1978: A global spectral model for simulation of the general circulation. J. Atmos. Sci., 35, 1557-1583.

Mechoso, C. R., M. J. Suarez, K. Yamazaki, J. A. Spahr and A. Arakawa, 1982: A study of the sensitivity of numerical forecasts to an upper boundary in the lower stratosphere. Mon. Wea. Rev., 110, 1984-1993.

Mintz, Y., 1964: Very long-term global integration of the primitive equations of atmospheric motion. Proceedings of WMO-IUGG symposium on the research and development aspect of long-range weather forecasting, Boulder, Colorado: WMO Tech. Note No. 66, 1965, 141-167; Amer. Met. Soc., Met. Monographs, Vol. 8, No. 30, 1968, 20-36.

- A. Katayama and A. Arakawa, 1972 : Numerical simulation of the seasonally and inter-annually varying tropospheric circulation. In "Survey conference proceedings of the climatic impact assessment program, Cambridge, Mass., 1972", Ed. A. E. Barrington 194-216, U. S. Dept. of Transportation.

Murakami, T. and M.S. Unninayar, 1977: Atmospheric circulation during December 1970 through February 1971. Mon. Wea. Rev., 105, 1024-1038.

Newell, R.E., J. W. Kidson, D. G. Vincent and G. J. Boer, 1972: The General Circulation of the Tropical Atmosphere and Interactions with Extratropical Latitudes, Vol. 1. The MIT Press, $258 \mathrm{pp}$.

The - , - and -1974 : The General Circulation of the Tropical Atmosphere and Interactions with Extratropical Lati. tudes, Vol. 2. The MIT Press, $371 \mathrm{pp}$.

Newton, C. W. (ed.), 1972: Meteorology of the Southern Hemisphere Meteor. Monogr., 13, No. $35,263 \mathrm{pp}$.

Nitta, Tsu., 1977: Response of cumulus updraft and downdraft to GATE A/B-scale motion systems. J. Atmos. Sci., 34, 1163-1186.

1978: A diagnostic study of interaction of cumulus updrafts and downdrafts with largescale motions in GATE. J. Met. Soc. Japan, 56, 232-241.

Oort, A.H. and E.M. Rasmusson, 1971: Atmospheric circulation statistics. NOAA Prof. Paper
5, U.S. Department of Commerce, Rockville, MD, $323 \mathrm{pp}$

- 1983: Global atmospheric circulation statistics, 1958-1973. NOAA Prof. Paper 14, U.S. Department of Commerce, Rockville, MD, 180 pp.

Pitcher, E. J., R.C. Malone, V. Ramanathan, M.L. Blackmon, K. Puri and W. Bourke, 1983: January and July simulations with a spectral general circulation model. J. Atmos. Sci., 40, 580-604.

Ramanathan, V., E.J. Pitcher, R.C. Malone and M.L. Blackmon, 1983: The response of a spectral general circulation model to refinements in radiative processes. J. Atmos. Sci., 40, 605-630.

Randall, D. A., 1976: The interaction of the planetary boundary layer with large-scale circulations. $\mathrm{Ph}$. D. Thesis, Univ. of Calif., Los Angeles, $247 \mathrm{pp}$.

Schlesinger, M. E. and W. L. Gates, 1980: The January and July performance of the OSU two-level atmospheric general circulation model. J. Atmos. Sci., 37, 1914-1943.

Schutz, C. and W.L. Gates, 1971: Global climatic data for, surface, $800 \mathrm{mb}, 400 \mathrm{mb}$ : January Advanced Research Projects Agency, Rep. R-915ARPA, Rand Corporation, Santa Monica, 73 pp.

Smagorinsky, J., 1963: General circulation experiments with the primitive equations: I. The basic experiment. Mon. Wea. Rev., 91, 99-164.

Stone, P. H., W. J. Quirk and R. C. J. Somerville, 1974: The effect of small-scale vertical mixing of horizontal momentum in a gèneral circulation model. Mon. Wea. Rev., 102, 765-771.

, S. Chow and W. J. Quirk, 1977: The July climate and a comparison of the January and July climates simulated by the GISS general circulation model. Mon. Wea. Rev., 105, 170-194.

Sumi, A. and T. Murakami, 1981: Large-scale aspects of the 1978-79 winter circulation over the greater WMONEX region. Part I: Monthly and season mean fields. J. Meteor. Soc. Japan, 59, 625-645.

- 1985: A study on cold surges around the Tibetan Plateau by using the numerical models. J. Met. Soc. Japan, 63, 377-396.

Tokioka, T., 1978: Some considerations on vertical differencing. J. Meteor. Soc. Japan, 56, 98-111. and A. Kitoh, 1982: January simulation of the tropical circulations with the MRI general circulation model. Extended abstracts of papers presented at the MSJ/JMA/WMO/AMS Regional scientific conference on tropical meteorology, Tsukuba, Japan, 18-22 October 1982.

- and I. Yagai, 1984: On the January simulation of stratospheric circulations with the MRI general circulation model: Preliminary results. Dynamics of the middle atmosphere, Terra Scientific Pub. Co., 527-537.

, K. Yamazaki, I. Yagai and A. Kitoh, 1984 : A description of the Meteorological Research Institute atmospheric general circulation model 
(the MRI·GCM-I). Tech. Reports of the Meteorological Research Institute, No. 13.

- and A. Kitoh, 1985: A simulation of the tropospheric general circulation with the MRI atmospheric general circulation model. Part III : The seasonal variation. (To be submitted for publication)

- - I. Yagai and A. Kitoh, 1985: On the comparative study of the January performances of the MRI.GCM with and without the stratosphere. (To be submitted for publication)

- and A. Noda, 1985: Effects of topography on January atmospheric circulation: A numerical experiment. (To be submitted for publication)

- 1985: Characteristics of long-term variations appeared in the perpetual January simulation with the MRI.GCM-I. (To be submitted for publication)

USSR NAVY, 1974: World Ocean Atlas, Vol. 1, Pacific Ocean, 320 pp.

-, 1977 : World Ocean Atlas, Vol. 2, Atlantic Ocean and Indian Ocean, $306 \mathrm{pp}$.

Washington, W. M., R. Dickinson, V. Ramanathan, T. Mayer, D. Williamson, G. Williamson and R. Wolski, 1979: Preliminary atmospheric simulation with the third-generation NCAR general circulation model: January and July. Report of the JOC Study Conference on Climate Models : Performance, Intercomparison and Sensitivity Studies, Washington, DC, 3-7 April 1978. GARP Publ. Ser., No. 22, 95-138.

Webster, P. J., 1981: Mechanisms determining the atmospheric response to sea surface temperature anamalies. J. Atmos. Sci., 38, 554-571.

Wei, M.Y., D.R. Johnson and R.D. Townsend, 1981: The structure of the planetary scale diabatic processes for the atmosphere during FGGE. ICSU/WMO GARP Condensed Papers and Meeting Report of the International Conference on Early Results of FGGE and Large-scale Aspects of its Monsoon Experiments, Tallahassee, Florida, (3-35)-(3-42).

Winninghoff, F. J., 1968: On the adjustment toward a geostrophic balance in a simple primitive equation model with application to the problems of initialization and objective analysis. $\mathrm{Ph}$. D. Thesis, Univ. of Calif., Los Angeles, $161 \mathrm{pp}$.

Yanai, M., S. Esbensen and J.-H. Chu, 1973: Determination of bulk properties of tropical cloud clusters from large-scale heat and moisture budgets. J. Atmos. Sci., 30, 611-627.

, J.-H. Chu, T.E. Stark and T. Nitta, 1976 : Response of deep and shallow tropical maritime cumuli to large-scale processes. J. Atmos. Sci., 33, 976-991.

\title{
気象研究所大気大循環モデルによる対流圈循環のシミユレーション 第 I 部 1 月の状態の再現実験
}

\author{
時岡達志・鬼頭昭雄・谷貝勇 - 山崎孝治 \\ 気象研究所
}

気象研究所大気大循環モデル (MRI·GCM) による1月の対流圈循環の再現宇験を行なった。MRI·GCM は UCLA·GCM (Arakawa and Mintz, 1974; Arakawa and Lamb, 1977) を基にし，力学及び物理過程の両面 で若干の修正，改良を行なっている。モデルの格子間隔は東西 5 度，南北 4 度である。モデルの上端は $100 \mathrm{mb}$ にあり, 大気は 5 層に分割している。海面水温, 海水の分布は気候值を与えている。他の変数はモデルによる 予報又は診断によって決定している。

モデルは大循環の基本的特徴を再現している。特に熱带域は良く再現できている。但し大気下層の水蒸気量 が気候值より過少になっている。南半球もほぼ良く再現できている。これに反して北半球ではいくつかの不一 致がみられる。その一つがチベット高原 (ここでは中国東北部及びシベリア南東部の地䚲も含めたものを指す) の近傍の流れである。モデルでは中国東部域の大気下層で北風成分が強過ぎる。又チベット高原南部域では東 風成分が強過ぎる。すなわち高気圧性の流れが強すぎる。この流れは冷たくて乾燥しており, ベンガル湾上で 蒸発が過剩になっており, 更に下流のインド洋赫道近傍で雨量が多過ぎる。この原因の一つとして, 寒気の侵 入を阻みやすい小さな地形の効果がモデルには不足していることが洘えられる。

他の不充分な点としてアリニーシャン低気圧が北東方问にずれ，その示度が深まり過ぎる点が挙げられる。 この点に関しても小さな地形の効果が不足していることが考兄られる。同時に事実関係としてモデル上部の極 域で気温が低下して拉り，アラスカからカナダ北西部にかけて安定度が恶くなっていることが指摘される。

モデルでは Arakawa and Schubert (1974) の理論に基づく積雲対流のパラメタリゼーションを行なってい る。この積雲モデルは低緯度域で組織的な降雨をもたらす。熱と運動量収支の点でこの積雲モデルが果たして いる役割についても示す。 